\title{
MATERIAŁY
}

Monika Nawrot

Bydgoszcz

\section{Wychowanie patriotyczne $w$ rodzinach polskich na terenie zaboru rosyjskiego $w$ drugiej połowie XIX i początkach wieku XX w świetle pamiętnikarstwa ${ }^{1}$}

Rodzina jest jedna z podstawowych grup społecznych, uważaną od najdawniejszych czasów za główną instytucję wychowawcza. Dlatego też refleksja nad rodziną w przeszłości pozwala na pełniejsze zrozumienie nie tylko jej mechanizmów wewnętrznych, ale również tradycji narodowych. „Rodzina funkcjonowała zawsze i funkcjonuje - jak stwierdza S. Kowalski - w wielostronnym i wielorakim powiazaniu ze społeczeństwem, którego jest elementarnym ogniwem. Choć więc rodzina stanowi najwcześniejsze podstawowe środowisko wychowawcze w życiu człowieka, to wychowuje nie tylko dla siebie, i nie tylko w imieniu własnym, ale i dla całego społeczeństwa, w jego imieniu i pod jego kontrola"

Rola rodziny szczególnie wzrosła na ziemiach polskich w okresie zaborów. Działo się tak ze względu na przekazywanie młodemu pokoleniu wartości osadzonych w tradycji i opartych na szacunku dla języka ojczystego, polskiej literatury, historii, zwyczajów i norm postępowania, szczególnie oczekiwanych przez tę część społeczeństwa polskiego, dla której utrzymanie tożsamości narodowej w młodych Polakach było celem nadrzędnym.

Formy prześladowań polskości były różne w poszczególnych dziesięcioleciach i na różnych obszarach państwa polskiego rozczłonkowanego między zaborców. Wspólna była natomiast jedna cecha - ograniczenie wszelkich narodowych form życia publicznego. Obrona odrębności narodowej nie była niestety celem całej ludności polskiej, ale jednak wśród dużej jej części istniała świadomość różnic od państwa zaborczego: językowej i obyczajowej. Ta część społeczeństwa, nie mogąc uczestniczyć w życiu publicznym, narodowym, nie mogạc swobodnie posługiwać się językiem ojczystym i zachowywać swoich tradycji i zwyczajów, zamknęła się w swoich domach. „Dom - jak pisze Ewa Deptuła-Jabłońska - stał się forma twierdzy, chroniącej przed niepożądanymi wpływami, rodzajem gniazda, w którym wychowywały się młode pisklęta" "3. Tu wpajano dziecku patriotyzm, miłość do ojczyzny, podstawowe wartości, skale ocen, które umożliwiały przeciwstawienie się, przynajmniej wewnętrznie, demoralizującemu wpływowi rusyfikacji, carskiej szkole. W życiu dorosłym natomiast

\footnotetext{
Artykuł powstał na podstawie jednego z rozdziałów pracy magisterskiej autorki, pt. Rola rodziny i nauczania domowego $w$ utrzymaniu tożsamości narodowej Polaków na terenie zaboru rosyjskiego $w$ drugiej potowie XIX wieku i poczalkach wieku $X X$ w świetle pamiętnikarstwa, wyróżnionej pierwsza nagroda w Ogólnopolskim Konkursie Prac Magisterskich z Historii Edukacji im. Profesora Czesława Majorka, edycja 2002/2003, zorganizowanym przez Zarzad Glówny Towarzystwa Historii Edukacji oraz Katedrę Historii Oświaty i Wychowania Akademii Pedagogicznej im. Komisji Edukacji Narodowej w Krakowie; wyróżniona praca powstała w Zakładzie Historii Myśli i Doktryn Pedagogicznych Akademii Bydgoskiej im. Kazimierza Wielkiego w Bydgoszczy, pod kierunkiem prof. dr. hab. Krzysztofa Jakubiaka.

${ }^{2}$ S. Kowalski, Socjologia wychowania w zarysie, Warszawa 1974, s. 116.

${ }^{3}$ E. Jabłońska-Deptułowa, Rodzino, dokad zmierzasz?, Poznań 1987, s. 25.
} 
tak ugruntowana postawa patriotyczna pozwalała skutecznie rozróżniać dobro od zla, dążyć do takiego kierowania swym życiem, by służyć dobru ojczyzny.

Analizujac zagadnienie wychowania patriotycznego w rodzinie polskiej, nie sposób pominąc definicji podstawowego dla prowadzonych ustaleń pojęcia, jakim jest patriotyzm. Określić go można jako postawę spoleczno-polityczna, formę ideologii narodowej, opartej na zasadzie miłości ojczyzny oraz poświęcenia się dla niej i dla narodu ${ }^{4}$. Postawę tę uzyskuje się w toku aktywności i praktyki, poprzez naukę, język, religię, świadomość polityczna i historyczną dotyczącą pochodzenia narodu, walk narodowowyzwoleńczych. Przejawia się ona także poczuciem związku emocjonalnego $\mathrm{z}$ własnym narodem, poszanowaniem, kultywowaniem i pielęgnowaniem jego wartości, ideałów, tradycji i kultury narodowej ${ }^{5}$.

Analizując stan badań i literaturę przedmiotu odnośnie głównego problemu badawczego niniejszego opracowania należy stwierdzić, iż problematyka ta, choć już podjęta badawczo, nie została jeszcze dokładnie rozpoznana ${ }^{6}$. Powstały wprawdzie prace dotyczace wychowania $w$ rodzinie na analizowanym terenie $\mathrm{i}$ podobnych ramach czasowych, lecz nie daja one pełnego obrazu polskich rodzin i pełnionych przez nie funkcji, a szczególnie tej z nich, która służyła kształtowaniu w młodym pokoleniu postawy patriotycznej. Dlatego też zamierzeniem niniejszego opracowania jest ukazanie tej strony wychowania $w$ rodzinach polskich (na terenie zaboru rosyjskiego $w$ drugiej połowie XIX i początkach wieku XX), która miała na celu wpojenie młodemu pokoleniu postawy patriotycznej.

Charakteryzując źródła, na których oparto analizę problematyki pracy, należy wskazać, że stanowi je szeroko pojęta literatura pamiętnikarska, więc pamiętniki, autobiografie, wspomnienia. Mimo, że były one już częściowo wykorzystywane do badań historyczno-pedagogicznych nad rodzina polska w XIX i XX wieku? ${ }^{7}$, stanowia drogocenny zbiór materiałôw źródłowych pozwalajacych na dokonanie

${ }^{4}$ K. Kotłowski, Rzecz o wychowaniu patriotycznym, Wrocław 1974, s. 16; Encyklopedia Polski, wstępem opatrzył T. Chrzanowski, Kraków 1996, s. 492.

5 J. Topolski, Świadomość historyczna Polaków, Łódź 1981, s. 20.

${ }^{6}$ Badania nad rola rodziny w wychowaniu patriotycznym młodego pokolenia podjęli do tej pory m.in.: J. Benyskiewicz, Rola rodziny w zachowaniu narodowości w warunkach zaboru [w:] Rola Wielkopolski w dziejach narodu polskiego, red. S. Kubiak, L. Trzeciakowski, Poznań 1979, s. 173 -183; S. Walasek, Wpływ rodziny na ksztattowanie się postaw patriotycznych wśród mtodziezy polskiej w Galicji (od II polowy XIX wieku do pierwszego dziesięciolecia XX wieku) [w:] Rodzina jako środowisko wychowawcze w czasach nowozytnych, red. K. Jakubiak, Bydgoszcz 1995 , s. 86-96; A. Ładyżyński, Rola rodziny w ksztaltowaniu postaw religijnych $i$ patriotycznych $w$ zaborze austriackim (1772 - 1914), ibidem, s. 96-106; A. Ładyżyński, Wptyw rodziny na ksztatiowanie się postaw religijnych $i$ patriotycznych dzieci i mtodzieży szlacheckiej w dobie zaborów 1772 - 1914 [w:] Studia z dziejów oświaty i myśli pedagogicznej $X I X$ i XX wieku, red. J. Szablicka-Żak, Wrocław 1998, s. 7-22; ustalenia istotne dla problematyki podjętego w niniejszym opracowaniu zagadnienia odnaleźć można także m.in. w następujących pracach: A. Winiarz, Rola i znaczenie matki w polskiej rodzinie magnackiej $i$ szlacheckiej $w$ XVIII $i$ XIX wieku, ciaglość $i$ zmiana [w:] Rodzina jako środowisko..., s. 61 -73; A. Winiarz, Czynniki determinujace proces wychowania w rodzinie polskiej doby niewoli narodowej (1795-19/8) [w:] Wychowanie w rodzinie polskiej od schytku XVIII do potowy XX wieku, red. K. Jakubiak, A. Winiarz, Bydgoszcz 2000, s. 51-103; Ł. Kabzińska, Rodzina jako podstawowe środowisko wychowawcze w pedagogicznych koncepcjach Królestwa Polskiego lat 1864-1918, ibidem, s. 139-161; A. Winiarz, Wptyw kobiety - matki na zycie polskiej rodziny ziemiańskiej doby niewoli narodowej (1795-1918) [w:] Partnerka, matka, opiekunka - status kobiety $w$ dziejach nowozytnych od XVI do XX wieku, red. K. Jakubiak, Bydgoszcz 2000, s. 147-156; K. Wróbel-Lipowa, Wychowanie dzieci w polskiej rodzinie ziemiańskiej w XIX wieku, ibidem, s. 73-81.

K. Bartnicka, Samodzielność wychowawcza rodziny ziemiańskiej w pierwszej potowie XIX wieku w zaborze rosyjskim (w świetle pamiętników) [w:] Wychowanie w rodzinie polskiej..., s. 32-50; A. Kicowska, Pamiętniki jakko źródlo do badań nad dzieckiem $i$ dzieciństwem [w:] Dziecko $w$ rodzinie i spoleczeństwie. Dzieje nowozytne, $t$. 2 , red. K. Jakubiak, W. Jamrożek, Bydgoszcz 2002, s. 301 - 31 L; E. Waksmund, Historia dziecka i dziecinstwa z perspektywy prozy wspomnieniowej, ibidem, s. $311-323$; K. Szafer, Dzieciństwo we wspomnieniach wielkopolskiej inteligencji i ziemiaństwa z przetomu XIX $i$ XX wieku, ibidem, s. 323 - 341; J. Borzyszkowski, Pamiętnikarstwo i sagi rodzinne jako świadectwo pomorskiej tożsamości [w:] Rodzina pomorska, red. J. Borzyszkowski, Gdańsk 1999, s. 73-92; K. Jakubiak, Wychowanie rodzinne i nauka domowa dziecka na Pomorzu w świetle polskich pamiętników z przełomu XIX i XX wieku, ibidem, s. 303-310; K. Kabziński, Pamiętniki w badaniach nad wychowawcza rola rodziny wiejskiej okresu międzywojennego, „Biuletyn Historii Wychowania” 1996, nr 1-2; M. Nawrot, Rola rodziny w utrzymaniu tożsamości narodowej Polaków na terenie zaboru rosyjskiego w drugiej polowie XIX i poczatkach wieku XX w świetle literatury wspomnieniowej i pamiętnikarstwa [w:] Acta Elblingensia. Rocznik Naukowy Elblaskiej Uczelni Humanistyczno-Ekonomicznej, t. 1, Elblag 2003, s. 51-71. 
w miarę szczegółowej i szerokiej analizy procesu wychowania patriotycznego w rodzinie w zaborze rosyjskim.

Z punktu widzenia naukowego pamiętnikarstwo można obarczyć wadą zbyt dużego subiektywizmu. $\mathrm{Z}$ drugiej jednak strony jest ono jednym $\mathrm{z}$ najdoskonalszych sposobów przekazu przeszłości. Pamiętniki sa bowiem źródłem szczególnym. Ich intymność $\mathrm{i}$ w wielu wypadkach ogromne walory literackie, a także głęboko ludzki wydźwięk sprawiają, że są one doskonałym materiałem dla historyka, stanowiąc istotny dokument epoki. Pamiętniki $\mathrm{z}$ badanego okresu nie ograniczają się bowiem tylko do relacji o perypetiach Polaków walczących o wolność, opisu sytuacji politycznych, ale wyłania się z nich także i druga warstwa, którą stanowia opowieści o życiu rodzinnym, funkcjonowaniu lokalnych społeczności, grona przyjaciół i znajomych. Mówią one wiele o nastrojach, poglądach, obyczajach i nawykach życiowych pokolenia, o faktach, ludziach i sprawach zwiazanych bezpośrednio $\mathrm{z}$ różnymi dziedzinami życia ich autorów.

Treści pamiętników zawierają się w kilku kręgach opisujących środowiska społeczne z których wywodzą się ich autorzy. Analizując źródła dostrzec można ogromne zróżnicowanie rodzin polskich, sposobów ich funkcjonowania w warunkach zaboru. Poznać można nie tylko ogólną atmosferę domów, ale i bogate życie wewnętrzne członków rodzin polskich, poszanowanie tradycji, wychowanie w duchu narodowym, w trosce o losy kraju. Można jednak spotkać także opisy rodzin, dla których walka o polskość nie była wcale nadrzędnym celem ich życia, a wychowanie patriotyczne nie miało miejsca.

W prezentowanych badaniach skupiono się głównie na pamiętnikach, wspomnieniach osób żyjacych w ówczesnym Królestwie Polskim. Analizy oparto na 105 pamiętnikach, pisanych przez bogate i średniozamożne mieszczaństwo ( 37 pamiętników), a także przedstawicieli rodzin szlachecko-ziemiańskich (68 pamiętników). Wspomnienia bowiem przedstawicieli tych właśnie warstw społecznych sa najszerzej opracowane i opublikowane. Wynika to zapewne $\mathrm{z}$ faktu, iż bogate klasy społeczne miały ułatwiony dostęp do oświaty i łatwiej mogły zdobyć wykształcenie, chętniej też i częściej opisywały losy swego życia. Głównym jednak argumentem dla oparcia niniejszych analiz na pamiętnikach przedstawicieli tych właśnie klas społecznych jest fakt, iż to w ich wspomnieniach odnaleźć można stosunkowo najwięcej obszernych wzmianek na temat wychowania w duchu miłości ojczyzny i poszanowania polskości.

Warto także zaznaczyć, iż blisko połowa analizowanych pamiętników napisana została przez kobiety (51 pamiętników). Jak bowiem pisała T. Duralska-Macheta, w wieku XIX nastąpiła prawdziwa eksplozja pamiętnikarstwa kobiecego. Szczególnie w Polsce sytuacja była specyficzna. Dziewczęta patrzyły na klęskę rozbiorów, rozumiały nieubłagany związek między sprawami narodu i rodzinnym bytowaniem. Miały więc o czym pisać. Życie, niegdyś spokojne, zamknięte w czterech ścianach domu, zostało narażone na katastrofy, które nadciagały $z$ zewnątrz. Do domów polskich wkraczała historia, zmieniając obyczaje, zmuszając „płeć piękną" do samodzielności, do współodpowiedzialności. Zabierała mężczyzn, którzy walczyli, ginęli w powstaniach, wywożeni byli na Sybir, szli na emigrację. Oznaczało to dla kobiet podjęcie walki o narodowość, język, kulturę, o wpajanie mlodemu pokoleniu postawy patriotycznej ${ }^{8}$. Wszystkie te działania odnotowane zostały we wspomnieniach i pamiętnikach spisywanych przez kobiety, ale także i mężczyzn.

Należy jednak pamiętać, że nie zawsze możliwa jest szczegółowa realizacja zamierzenia badawczego. Zależna jest ona bowiem od ilości źródeł pisanych. Wart podkreślenia wydaje się tu fakt, iż życie rodzinne minionych lat nie zawsze znajdowało swe odzwierciedlenie na piśmie, badź to $z$ braku chęci członków rodzin, bądź z powodu braku wykształcenia. Stan literatury źródłowej nie jest więc w pełni kompletny, lecz można stwierdzić, że wystarczajacy dla zbadania podjętej tu problematyki.

Wychowanie patriotyczne, mające także na celu utrzymanie tożsamości narodowej, zależnie od rodziny przyjmowalo bardziej lub mniej sformalizowane warianty. Nie zawsze miało charakter intencjonalny i świadomy, a jego przebieg nie we wszystkich przypadkach był w pełni zorganizowany,

\footnotetext{
Kufer Kasyldy, czyli wspomnienia z lat dziewczęcych, oprac. T. Duralska-Macheta, Warszawa 1983, s. 7.
} 
systematyczny i nie pozbawiony wad, błędów. Postawy patriotyzmu przekazywane były bowiem dzieciom przez wszystkich niemal członkỏw rodziny: rodziców, dziadków, ciotki, wujków, starsze rodzeństwo, rezydentów, nianie, nauczycieli domowych, a nawet służbę. Wszystkie te osoby często intuicyjnie, nieświadomie przekazywały swym pociechom swoja wiedzę, poglądy, przekonania, systemy wartości. Częsć z nich, szczególnie pod koniec XIX i w poczatkach wieku XX, podlegać zaczęła różnym wpływom, jak np. poradników dla rodziców, prasy rodzinnej i pedagogicznej, odczytów, wykładów, które tworzone były w celu podniesienia kultury pedagogicznej rodziców i podkreślały znaczenie roli rodziny w kształceniu a także $w$ wychowaniu patriotycznym dzieci i młodzieży. Na skutek wszystkich tych oddziaływań rodzina polska uległa istotnym przemianom, zaznaczając swój coraz większy udział w kształtowaniu postaw patriotycznych młodego pokolenia.

Jak wykazuje analiza źródeł pamiętnikarskich, rodzina polska drugiej połowy XIX i początku wieku XX dysponowała wieloma różnymi środkami wychowawczymi. Do niezmiernie ważnych zaliczyć należy prasę i książkę polska, kultywowanie polskich obyczajów, śpiewanie pieśni narodowych i ludowych. Najwięcej treści patriotycznych przekazywano dzieciom właśnie w trakcie wspólnych dyskusji, lektury i śpiewu. Rozmowom z dorosłymi często towarzyszyła prezentacja różnych domowych pamiątek, obrazów, sztychów, fotografii, starych dokumentów, bibelotów, książek i broni. Portrety przodków, bohaterów narodowych, pośród których nie mogło zabrakną́ Stefana Czarneckiego, Jana III Sobieskiego, księcia Józefa Poniatowskiego, Tadeusza Kościuszki, były ilustracjami do opowieści snutych przez starszych. Owe przedmioty miały ogromną wartość dydaktyczna, raz opatrzone odpowiednim komentarzem historycznym, służyły przez długie lata jako symbole przeszłości, tradycji narodowej i rodzinnej.

Jeden z pamiętnikarzy, August Iwański, wspominał, iż ojcjec jego bardzo dbał o patriotyczne wychowanie swych synów. Dobierał w tym celu różnorodne metody i środki pedagogiczne. Ideałem jego było wychowanie chłopców na światłych Polaków, obywateli-ziemian, przyczyniających się do rozwoju spoleczeństwa i narodu. Majątki rodzinne, które w ich rękach miały rozkwitać i rozrastać się nakazywał traktować jako własność narodowa. Istotne wychowawczo było według ojca nawet umeblowanie domu, a także dobór odpowiedniego towarzystwa rówieśników i dorosłych".

Ważnym czynnikiem wychowania patriotycznego było to, iż często, nawet w sposób dyskretny, przemycano najważniejsze fakty $z$ dziejów narodowych (dane na ten temat zawierają 72 ze 105 analizowanych pamiętników). Były one odpowiednio upiększone i zbeletryzowane, aby najmłodsi mogli je sobie dobrze przyswoić ${ }^{10}$. W obawie przed donosami wielu tematów unikano, szczególnie gdy dotyczyły one faktów z powstań narodowych. Romana Pachucka tak opisywała rodzinne tradycje powstaniowe i ich wpływ na wychowanie młodego pokolenia: „Za czasów mego dzieciństwa te

"Umeblowanie byto najprostsze, stoty, twarde krzesta, tózka celowo twarde, z tosiowymi skórami pod prześcieradtami. Na ścianach poczatkowo sztychy $i$ reprodukcje, z czasem zmienione na dobre obrazy pierwszorzędnych mistrzów pedzla. Urzadzenie to i umeblowanie wybornie charakteryzowato ojca $i$ jego metody pedagogiczne: chodziło o wyrobienie w nas silnych charakterów, wolnych od wszelkiej miękkości i rozpieszczenia. o przeciwdziatanie ujemnym skutkom naszej zamożności. Wszelkie nadmierne używanie życia i rozrzutność uważane byty za wady, które $w$ pierwszej linii nalezato plenić $w$ zarodku. Pod katem przydatności i celowości dobierane było takze towarzystwo, w klórym obracaliśmy sie. Ojciec starannie omijat i unikał panków i pótpanków kresowych, otaczat natomiast siebie $i$ nas ludźmi światlymi i przodujacymi (A., A. Iwańscy, Pamięmiki 1832-1876, Wspomnienia $1881-1939$, Warszawa 1968 , s. $273-274$ ).

${ }^{10} \mathrm{O}$ opowieściach czlonków rodziny o istotnych wydarzeniach narodowych wspominają m.in.: M.K. Dziewanowski, Jedno zycie to za mato. Kartki z dziennika niepoprawnego optymisty, Warszawa 1999, s. 39: M. Szypowska, Asnyk znany i nieznany, Warszawa 1971, s. 27; K. Pruszyński, Wspomnienia, reportaże, artykuly, t. 1, Warszawa 2000, s. 34, 54 - 56; G. Brzęk, Benedykt Dybowski. Zycie i dzieto, Lublin 1988, s. 12 - 13; E. Polanowski, Maria Dabrowska. W krainie dziecinstwa $i$ mtodości, Poznań 1989, s. 47; B. Suchodolski, Seweryn Goszczýnski. Życie $i$ dzieto, Warszawa 1950, s. 10, 12; E. Sukertowå-Biedrawina, Dawno a niedawno. Wspomnienia, Olsztyn 1965, s. 7-8; C. Czarnocki, Strzepy wspomnień. Szkice autobiograficzne, Warszawa 1973, s. 30-31; T.T. Jeż (Z. Miłkowski), Od kolebki przez zycie. Wspomnienia, Kraków 1936, s. 3; B. Krzywobłocka, Delfina i inne, Warszawa 1988, s. 148; M. Jałowiecki, Na skraju imperium, Warszawa 2000, s. 15-17; J. Horoszkiewicz, Notatki z zycia, Wrocław-Kraków 1957, s. 16 - 18; E. Wróblewska, Józef Feliks Zieliniski (Izet-Bey), Toruń 1963, s. 10; E. Rudzki, Delfina Potocka, Warszawa 1990, s. 12; M. Witkiewiczówna, Wspomnienia o Stanistawie Witkiewiczu, Warszawa 1936, s. 8. 
powstaniowe tradycje rodzinne były żywo komentowane i podtrzymywane. Mówiło się o nich to $z$ dumą, to przyciszonym głosem, jak tajemnice, to z bólem i żalem. Wiązały one pokolenia z pokoleniami, uczyły żywym przykładem zaczerpniętym z dziejów ludzkich, zachęcały do czynów szlachetnych, wskazywały pola pracy dla ambicji młodych, przestrzegały przed nierozwaga i podstępem" ". Maria Grodzicka wspominała, iż wszyscy niemal członkowie rodziny opowiadali często o udziale przodków w wojnach, powstaniach i walkach narodowowyzwoleńczych. Dzieci od najmłodszych lat pochlaniały opowiadania prababki, starszych ciotek, matki. Szczególnie przez nie lubiany był cykl opowiadań dotyczący powstania listopadowego i udziału w nim dziadków, prababci, ciotek, który odbywał się codziennie w długie, jesienno-zimowe wieczory. Wyjątrowo żywy w rodzinie byl kult dziadka Filipa Grodzickiego, Sybiraka, który osiemnaście lat spędził na wygnaniu w tajgach Sybiru. Pamięć o jego cierpieniach i męstwie towarzyszyła najmłodszym w każdej sytuacji: „Wyrabiano w nas świadomość, że przykład jego czynów obowiązuje i nas, bo mając taką spuściznę rodową musimy stać się jej godni" ${ }^{2}$. Również matka często wspominała dawne czasy, lecz gdy dochodziła do powstania styczniowego 1863 roku, milkła, zapadała w zadumę i dzieci rozumiały, że kryła się za tym jakaś szczególna zadra i boleść. Śpiewała także często, wspólnie z dziećmi pieśni z tego okresu: „Mama siadała machinalnie do fortepianu i śpiewała to, czego słowami nie mogła wypowiedzieć, na przykład " $Z$ dymem pożarów «" 13 .

Z czasem jednak atmosfera tajemniczości przekazów uległa zmianie i najróżniejsze, obszerne, pozbawione jakichkolwiek zafałszowań czy niedomówień fakty historyczne docierały do dzieci i młodzieży. Przede wszystkim obecność weteranów z 1863 roku w niejednym domu ułatwiała dzieciom poznanie zakazanych informacji.

Jednym $z$ przejawów wychowania patriotycznego był fakt, iż dzieciom zaszczepiano wrogi stosunek do wszystkiego, co miało cokolwiek wspólnego z Rosja ${ }^{14}$ (informacje potwierdzające ten fakt znajdujemy w 27 pamiętnikach). Wspomniana Romana Pachucka pisała, iż Polacy żyli swoim życiem, odrębnym od życia zaborców. Nie łączyły ich z nimi żadne towarzyskie kontakty, a jedynie te oficjalne lub zawodowe. „W naszej rodzinie obowiazywało to samo nastawienie. Nikt $z$ Rosjan nie bywał u nas, ani my u rodzin rosyjskich. Dzieci patrzyły ze zgrozą na żandarmów i kozaków jadących z nahajami przez miasto, usuwały się z drogi oficerom. Tchnienie powstania styczniowego działało" 15 .

Podobna atmosfera nienawiści i otwartej wrogości dla zaborcy panowała $w$ domu Teodory z Kosmowskich Krajewskiej. Choć rodzice jej mieszkali w jednym z pawilonów pałacu Kazimierzowskiego, gdzie mieściło się biuro Warszawskiego Naukowego Okręgu, matka jej nie znała się z żadną z Rosjanek, żon zamieszkałych tam zwierzchników męża, i nawet żadnej z nich nie pozdrawiała. „Iskra miłości ojczyzny tlała (...) Wszyscy wiedzieli, że matka ani słowa po rosyjsku nie umie, a także, że nie ma najmniejszego zamiarı uczyć się tego języka. Rosjanie stanowili bowiem dla nas świat obcy"16.

Matka braci Plawińskich śpiewała swym synom kołysankę, której jedna ze strofek miała zdecydowanie antycarski charakter:

„Car Tobie jeść nie da, kozakowi Cię sprzeda,

U kozaków mrozy i rózeczka z brzozy.

Cicho dziecię, lulaj, do mnie się przytulaj" "1?.

" R. Pachucka, Pamiętniki z lat 1886-1914, Wrocław 1958, s. 11.

12 M. Grodzicka, Wśród polskich pól przed laty: wspomnienia, Włocławek 2000, s. 23.

${ }^{13}$ Ibidem.

${ }^{14} \mathrm{O}$ fakcie zaszczepiania w dzieciach nienawiści do zaborcy pisali m.in.: M. Wolska, B. Obertyńska, Wspomnienia, Warszawa 1974, s. 501; M. Kasprowiczowa, Dziennik, Warszawa 1958, s. 154; K. Iłłakowiczówna, Wspomnienia i reportaze, Warszawa 1997, s. 32 -33; K. Pruszyński, op. cit., s. 22; W. Jędrzejewicz, Wspomnienia, Wrocław-Warszawa-Kraków 1993, s. 7; J. Kallenbach, Z. Krasiński. Zycie i wórczość lat mtodych, t. 1, Lwów 1904, s. 36; Pamiętniki Ignacego Baranowskiego, oprac. A. Wrzosek, Poznań 1923, s. 7, 31; W. Ambroziewicz, Moja przygoda pedagogiczna. O polskiej szkole nieco inaczej, Warszawa 2000, s. 32; M. Jałowiecki, op. cit., s. 15; I. Baliński, Wspomnienia o Warszawie, Warszawa 1987, s. 23; L. Bochwic, Wspomnienia uniwersyteckie. Warszawa 1882 - 1885. Petersburg 1885-1887, t. 1, Wilno 1938, s. 27.

13 R. Pachucka, op. cit., s. 13; H. Arturowa Rodzińska, Nasze wspólne życie, Warszawa 1981, s. 46.

16 T. z Kosmowskich Krajewska, Pamiętnik, Kraków 1989, s. 45.

17 J. Targalski, Pierwsi buntownicy, Warszawa 1967, s. 30. 
Warto wskazać, iż w rodzinach polskich walka z rusyfikacja objęła też taką dziedzinę jak nadawanie imion. Unikano tych używanych często przez prawosławnych, np. Mikołaj. Zdecydowanie dominowały imiona polskie, a szczególnie często nadawano dzieciom imiona po przodkach-patriotach, bohaterach narodowych, biorących czynny udział w walkach narodowowyzwoleńczych, powstaniach.

$\mathrm{Na}$ pogłębienie edukacji patriotycznej wpływały kontakty z rówieśnikami, rodziną i znajomymi $z$ innych zaborów, szczególnie, gdy towarzyszyły temu wyjazdy (potwierdzaja to 24 pamiętniki). Powszechnie wiadomo było, że podróże kształca, lecz twierdzono także, że są jeszcze i inne podróże, które służą poszukiwaniu przeszłości, poszukiwaniu echa wielkości własnej ojczyzny, niegdyś potężnej, dziś uciemiężonej. We wspomnieniach Marii Skłodowskiej-Curie czytamy: „Opuszczaliśmy granice zaboru rosyjskiego udając się do Galicji, gdzie ucisk austriacki był mniej dokuczliwy niż u nas. Tam można było zupełnie swobodnie mówić po polsku i śpiewać pieśni patriotyczne nie lękając się więzienia" 18 . Szczególnie silne wrażenie pozostawiał na dzieciach z zaboru rosyjskiego Kraków, który, jak to określił jeden z pamiętnikarzy, posiadał specyficzną atmosferę polskości, „bardzo podniecająca dla spragnionych wolności »koroniarzy " $"$. Było to miasto w którym koncentrowało się i kwitło życie narodowe, nauka, sztuka, literatura, teatr. P. Górska wspominała, iż jadąc tam jako mała dziewczynka, brała udział $w$ licznych obchodach rocznic narodowych, sztukach patriotycznych, śpiewała wraz z innymi hymn narodowy, a ,wszystkie te sprawy krzyżowały się, tloczyły, tworzą gorąca i patriotyczną atmosferę, która nas, ludzi z Kongresówki, po prostu upajała"20.

Ważnym elementem wychowania patriotycznego, jak wynika $z$ analizy źródel pamiętnikarskich, były spacery i wycieczki do miejsc zwiazanych z ważnymi dla narodu polskiego wydarzeniami historycznymi (informacje na ten temat zawiera 19 pamiętników). Jadwiga Łuszczewska wspominała, iż rodzice jej, by unaocznić dzieciom miejsca istotnych wystapień, bitew, wojen, wozili je tam tak często, jak tylko pozwalał im na to czas i okoliczności. „Rodzice wozili nas po okolicach Warszawy - pisała pamiętnikarka - do miejsc pamiętnych czy to elekcjami, czy bitwami, a zwłaszcza do Wilanowa. Tam pokazywali nam królewskie pokoje, i już od dzieciństwa wżyłam się w epokę Sobieskiego, która mnie odtąd nieprzeparcie pociagała"2i.

Helena Duninówna opisywała, jak rodzice jej, obok opowieści o powstaniu, nauki wierszy i pieśni z tamtego okresu, zawsze starali się w różnorodny sposób upamiętniać wydarzenia związane z sześćdziesiatym trzecim i trzydziestym rokiem wieku XIX. Jednym z tych sposobów były wlaśnie liczne wycieczki i wyprawy w miejsca, gdzie odbywały się najistotniejsze dla Polaków wydarzenia. „Zaczeliśsmy od ulicy Miodowej - wspominała pamiętnikarka. Przy rogu Kapitulnej pierwszy postój. Dowiedzieliśmy się, że tu właśnie, w tym małym lokaliku, zbierała się studencka młodzież Warszawy, tu budzily się pierwsze rewolucyjne bunty, powstańcze plany i projekty"22.

Klęska powstania 1863 roku spowodowała w polskich rodzinach, obok ogólnego przygnębienia, wzrost uczuć patriotycznych. Powodowało to, iż większość rozmów, spotkań towarzyskich, dotyczyła

${ }^{18}$ M. Sklodowska-Curie, Autobiografia, Warszawa 1959, s. 14.

${ }^{19}$ K.M. Górski, J. Waysenhoff, Z młodych lat. Listy $i$ wspomnienia, Warszawa 1985, s. 23.

${ }^{20}$ P. Górska, Paleta i pióro. Wspomnienia, Kraków 1956, s. 58; wyjazd do Krakowa, poprzedzające go specjalne przygotowania w zakresie historii i zabytków miasta, a także zwiąane z nim wrażenia opisuja m.in.: M. Wolska, B. Obertyñska, op. cit., s. 26; W. Grabski, Blizny dziecinistwa, Warszawa 1971, s. 37; K. Skirmunt, Moje wspomnienia I866-1945, Rzeszów 1998, s. 23; A. Jełowicki, Moje wspomnienia, Warszawa 1970, s. 39.

21 J. Euszczewska, Pamiętnik 1834 - 1897, Warszawa 1968, s. 70; B. Krzywoblocka, op. cit., s. 153; ojciec jednego z pamiętnikarzy zabieral chlopca na wycieczki w miejsca walk narodowowyzwoleńczych, prowadzac tam "lekcje pogladowe z zakresu narodowego patriotyzmu" (Z. Sudolski, Krasiński. Opowieść biograficzna, Warszawa 1977 , s. 58); ojciec S. Michalskiego w nagrodę za dobre wyniki w nauce zabierał chłopca na wycieczki do Warszawy, Częstochowy, gdzie uczęszczali do teatru, zwiedzali zabytki, a ,wszystko to wywarto na mnie wielkie wrazenie, mialo duzy wplyw wychowawczy, poznatem bowiem czesśc Polski nie z opisu, a z osobistego zwiedzania" (Stanisława Michalskiego autobiografia $i$ działalność oświatowa, red. H. Radlińska, 1. Leparczyk, Wroclaw-Warszawa-Kraków 1967, s. 195, 201); podobnie o wycieczkach takich wspominaja: B. Krzywobłocka, op. cil., s. 197; D. Wawrzykowska-Wierciochowa, Muza Stowackiego i Chopina. Opowieśc biograficzna o Marii Wodzińskiej, Warszawa 1986, s. 23; G. z Guntherów Puzynina, W Wilnie i dworach litewskich. Pamiętnik, Kraków 1988, s. 77 -79.

${ }^{22}$ H. Duninówna, Odeszło-żyje, Łódź 1961, s. 108-109. 
rozpatrywania przyszłych losów Polski i było wyrazem troski o losy kraju. Po powstaniu styczniowym Polki ostentacyjnie nosiły żałobę. Także dzieci rozumiały tę wyjątkową sytuację i czynnie się w nia właczały (wspominało o tym 11 pamiętnikarzy). Anna z Działyńskich Potocka pisała, iż ojciec jej szczególnie dbał o przestrzeganie wśród rodziny i znajomych tego doniosłego zwyczaju. „Ojciec mój nie pozwalał tańczyć w swoim domu; na samą wzmiankę o tańcach oburzał się. U niego żałoba narodowa przechodziła w żałobę familijna. Klejnotów córkom swym nosić nie pozwalał nigdy, uważał, że one polskiej niewieście nie przystoja" ${ }^{23}$. Także Marian Bosco-Bogdanowicz obszernie w swych wspomnieniach podkreślał istotę i znaczenie żałoby narodowej dla życia całej rodziny, a szczególnie dzieci. „Żałoba narodowa nadawała upiorne ponure piętno całemu otoczeniu lat mojego dzieciństwa” 24 - pisał pamiętnikarz. Matki i babki ubierały czarne suknie i kwefy. Ojcowie i dziadowie w wielu domach poubierali czamary, które niejednokrotnie nosili do końca życia ${ }^{25}$. Zaprzestano się bawić i tańczyć. Całe młode pokolenie w rodzinie autora wspomnień wychowane było $w$ gorącym patriotyzmie. $\mathrm{Na}$ imieniny rodziców lub dziadków dzieci uczyły się, zamiast powinszowań, „Śpiewów Historycznych" J. U. Niemcewicza. Po pierwszych lekcjach fortepianu popisywali się "Chorałem", utworami Józefa Nikorowicza ${ }^{26}$.

Jak wskazuje już fragment wspomnień Mariana Bogdanowicza, jednym z najbardziej cenionych przez rodziców prezentem imieninowym były deklamacje wierszy patriotycznych, których uczyły się dzieci (fakt ten potwierdza 16 pamiętników). Było to $\mathrm{z}$ pewnościa istotnym elementem wychowania patriotycznego realizowanego przez rodziny polskie $W$ analizowanym okresie. Ignacy Baliński wspominał wyjątkowy dzień w roku, którym był właśnie dzień imienin rodziców: „Głównym dniem popisu uczącej się w naszym domu dziatwy był święty Józef, dzień imienin obojga rodziców (...) Na ostatni Święty Józef w 1873 roku przed wyjazdem do szkól deklamowałem »Alpuharę« $\mathrm{z}$ »Wallenroda«" 27 .

Maria Grodzicka wspominała, iż w jej rodzinie panował zwyczaj, iż z okazji imienin rodziców dzieci deklamowały wyuczone wiersze. Wybierały je najczęściej samodzielnie, według własnego gustu i uznania, bądź pod kierunkiem domowej nauczycielki. „Pamiętam imieniny taty, szczególnie dla mnie ważne - pisała Grodzicka - Miałam duży bukiet róż, a w głowie kłębiace się strofy wiersza Mickiewicza "Śmierć Pułkownika«. Był to ulubiony wiersz taty. Gdy przyszła kolej na Stasia, mówił z III części »Dziadów « fragment wywożenia kibitkami chłopów na Syberię. Gdy skończył, ojciec powiedział wzruszony: "Duch twego dziada Sybiraka przemówil przez twoje usta « ${ }^{28}$.

Istotnym elementem wychowania patriotycznego, mającego na celu wzbudzenie szacunku i pamięć poległych bohaterów narodowych było wieńczenie przez dzieci na Wszystkich Świętych grobów zasłużonych, jeśli takie były w pobliżu, noszenie wiązanek, palenie lampek, śpiewanie pod krzyżami powstańców wspólnie z dorosłymi „Boże coś Polskę”, ,ZZ dymem pożarów”, a także innych pieśni patriotycznych, których uczyli ich. rodzice czy dziadkowie ${ }^{29}$.

\footnotetext{
${ }^{23}$ A. z Działyńskich Potocka, Mój pamiętnik, Warszawa 1973, s. 25.

${ }^{24}$ M.B. Bogdanowicz, Wspomnienia, Kraków 1959, s. 73.

${ }_{25}$ Szacunek dla polskiego narodowego stroju podkreślali w swych wspomnieniach także: J. Horoszkiewicz, op. cit., s. 9; Z. Sudolski, Krasinski..., s. 44.

${ }^{26}$ Ibidem; o popisach fortepianowych $\mathrm{z}$ wykorzystaniem utworów wybitnych kompozytorów polskich pisali m.in.: M. Wolska, B. Obertyńska, op. cit., s. 406; D. Wawrzykowska-Wierciochowa, op. cit., s. 23, 31; Z. Ordyńska [w:] Kufer Kasyldy..., s. 460.

${ }_{27}$ I. Baliński, op. cit., s. 31; G. z Guntherów Puzynina tak wspominała imieniny swej babki: ,Dzień imienin babki úwietnił się od samego ranka obrazem z »Żywota Swiętej Elżbiety« (...) Wieczorem widowisko rozpoczęto obrazem zywym, ztozionym z samych wnuczat $w$ bieli, śpiewajacych hymn do Najświętszej Panny, a Helenka odczytywała wiersze (...)" [w:] G. z Guntherów Puzynina, op. cit., s. 263 -264; podobnie o imieninowych deklamacjach patriotycznych wierszy polskich poetów pisali m.in.: K. Pollack, Ze wspomnień starego dziennikarza warszawskiego, Warszawa 1987. s. 30; J. Waydel-Dmochowska, Jeszcze o dawnej Warszawie, Warszawa 1960, s. 73.

${ }^{28}$ M. Grodzicka, op. cit., s. 65 .

${ }^{29} \mathrm{~S}$. Wojciechowski tak pisał o spacerach w miejsca, gdzie znajdowały się groby powstańców: ,,(...) pokazywano nam ukryte w ogrodach i lasach mogiły powstańców (...) Wszystko to rozbudzato $w$ nowym pokoleniu gorace uczucia patriotyczne" [w:] S. Wojciechowski, Moje wspomnienia, t. 1, Lwów-Warszawa 1935, s. 7.
} 
Równie istotnym elementem kształtującym postawy patriotyczne były urządzane $-\mathrm{z}$ udziałem dzieci - wieczory deklamacji ${ }^{30}$ (informacje na ten temat znajdujemy w 38 pamiętnikach). Recytowano głównie utwory Adama Mickiewicza, Zygmunta Krasińskiego, Juliusza Słowackiego, ale zdarzało się, że i innych poetów. Wieczorkom tym często towarzyszyła gra na fortepianie, czy śpiew. Repertuar czerpano głównie ze „Śpiewników domowych” Moniuszki, a także chętnie grywano Chopina i pieśni patriotyczne czy narodowe. Także nieodłącznym elementem wieczomych spotkań rodzinnych było czytanie polskiej prasy, książek, ulotek politycznych, poezji. Stefania Wilska wspominała owe zebrania rodzinne, połączone z rozprawami na temat historii kraju, jego przyszłości, z deklamacjami, wspólnym czytaniem i muzykowaniem: „Otóż na naszych spotkaniach deklamacja była uprawiana głównie przez brata Hipolita, który obok trójcy narodowych wieszczów - Adama, Zygmunta i Juliusza, dawał nam poznać także i innych autorów. Grywano u nas także pięknie na fortepianie (...) Nie było dnia, żeby ktoś z przyjezdnych lub miejscowych gości nie uczestniczył w wieczornych pogawędkach i wspólnym czytaniu" 31 .

Warto nadmienić, iż na początku XX wieku w domach polskich popularne stały się teatry amatorskie (23 pamiętniki). Głównie z tak zwanymi żywymi obrazami. Oczywiście w odgrywanie najróżniejszych ról i postaci włączano także dzieci. Z reguły zawsze przedstawienia dobierano tak, by zawierały wątek patriotyczny. Kazimiera Treterowa wspominała, iż ciotka jej zajmowała się przygotowywaniem przedstawień amatorskich właśnie specjalnie dla dzieci. Zawierały one wiersze o charakterze i nastroju narodowym, polskie utwory odgrywane na fortepianie, pieśni, patriotyczne monologi, czasami nawet fragmenty komedyjek. Programy tych teatrów często rodziny pożyczały sobie, wymieniały się nimi, a także wzajemnie uczestniczyły w wystawianych sąsiedzkich przedstawieniach. „U państwa Pektunków - pisała pamiętnikarka - grano "Zaczarowane koło« Rydla, grało się i u nas w domu komedyjkę cioci »Wandzia Księżniczka«, a ostatnim numerem był żywy obraz "Apoteoza Polski«" 32 .

Sposobem wpływajacym na kształtowanie postaw patriotycznych dzieci było z pewnościa prezentowanie pamiątek rodowych i narodowych. W wielu bowiem pamiętnikach odnaleźć można obszerne wzmianki na temat wykorzystywania tychże historycznych przedmiotów w celu rozbudzenia w sercach najmłodszych miłości do ojczyzny (potwierdzają to 32 pamiętniki). W każdym prawie domu zachowane były mniej lub bardziej liczne pamiątki po przodkach, które otaczane były legendą. Rodzice chętnie i często wykorzystywali je do opowiadań o historii rodziny i kraju. Często też dzieci spotykały się $\mathrm{z}$ tymi przedmiotami w rodzinach i domach zaprzyjaźnionych czy sąsiedzkich. Wychowywały się pośród nich. Zwłaszcza obrazy działały silnie na wyobraźnię dziecięca ${ }^{33}$. Portrety ostatniego króla,

${ }^{311} \mathrm{O}$ deklamacjach urządzanych w salonach rodzinnych wspominaja m.in.: M. Wołska, B. Obertyńska, op. cit., s. 143; W. Jędrzejewicz, op. cit., s. 8; J. Porazińska, I w sto koni nie dogoni. Gawęda o moim dzieciństwie, Warszawa 1988, s. 20; B. Krzywobłocka, op. cit., s. 148; M. Skłodowska-Curie, Autobiografia, Warszawa 1959, s. 13; A. Jelowicki, op. cit., s. 8; S. Miłaszewski, Wspominamy, Poznań-Lublir 1939, s. 16; F. Kalicka, Julian Brun-Bronowicz. Życie, działalność, twórczość, Warszawa 1973, s. 13-14; D. Wawrzykowska-Wierciochowa, op. cit., s. 23; J. Michalski, 55 lat wśród ksiazek. Wspomnienia, wrazenia, rozważania, Wroclaw 1950, s. 2; J. Waydel-Dmochowska, Dawna Warszawa, Warszawa 1958, s. 18-19; J. Korolewicz-Waydowa, Sztuka i zycie. Mój pamiętnik, Wroclaw 1958, s. 21 .

31 S. Wilska, Pamiętnik o lgnacym Chmielinskim, Wrocław 1952, s. 12.

32 K. Treterowa, Reportaz z mojego zycia. Wspomnienia, Wroclaw 1952, s. 50; o fakcie organizowania teatrzyków amatorskich z udziałem dzieci pisali m.in.: M. Wolska, B. Obertyńska, op. cit., s. 36, 143; P. Matusik, Religia i naród. Życie i myśl Jana Koźmiana 1814-1877, Poznań 1998, s. 30; M. Romankówna, Narcyza Żmichowska (Gabriella), Kraków 1970, s. 26: W. Źółkiewska, Maniusia, Warszawa 1983, s. 63; A. Nowakowski, Swiatto dla Warszawy. Wspomnienia, Warszawa 1973, s. 16; W. Źółkiewska, Przyjaciele mojego dziecińntwa, Warszawa 1986, s. 106; F. Kalicka, op. cit., s. 14; J. Waydel-Dmochowska, op. cit., s. 128; G. z Guntherów Puzynina, op. cit., s. 262-263; Z. z Fredrów Szeptycka, Wspomnienia z lat ubiegtych, Wrocław-Warszawa-Kraków 1967, s. 49.

33 ,.Patriotyzm manifestowal się w (...) obrazach $i$ kopiach obrazów, upiększajacych ściany salonu $i$ jadalni (...) $W$ naszym salonie na ścianach, $w$ wielkich ztoconych ramach wisialy kopie wielkich malarzy Matejki i Styki, a w skromniejszej oprawie caly cykl "Polonia" Grottgera, portrety królów Polski, wybitnych Polaków, jak np. Stefana Czarnieckiego, Piotra Skargi, Mikotaja Kopernika, Tadeusza Kościuszki" (S. Wloszczewski, Na przetomie dwóch epok, Warszawa 1974, s. 16); podobnie o edukacyjnej roli obrazów i sztychów pisal m.in. J.T. Mieszkowski, Wspomnienia dziennikarza socjalisty, Warszawa 1971, s. 8. 
Stanisława Augusta, księcia Józefa Poniatowskiego, po kolejnych powstaniach także wizerunki wybitnych ich uczestników, znajdowano na ścianach w zamożniejszych domach. Kilkuletni Ludwik Jabłonowski, powstaniec, w swym pamiętniku wspominał to, co zapamiętał $\mathrm{z}$ lat wczesnego dzjeciństwa: „Do Kolbuszowej państwa Tyszkiewiczów wstąpiliśmy na nocleg. Tam pierwszy raz widziałem na portrecie Jarosława Tyszkiewicza, poległego pod Borodino, polski mundur" ${ }^{34}$.

Jadwiga z Sikorskich Klemensiewiczowa opisując salon w domu rodzinnym podkreślała wpływ obrazów na rozwój jej i jej sióstr. Twierdziła, iż przytulny salon i rozwieszone w nim obrazy bardzo skutecznie pobudzały uczucia dziewcząt w kierunku poetyckim, patriotycznym, bohaterskim, podróżniczym. Były tam między innymi sztychy wyobrażajace księcia Józefa Poniatowskiego skaczącego na koniu w nurty Elstery, który .,przejmował je szczególnym uwielbieniem dla bohatera" ${ }^{35}$. Anna Skarbek-Sokolowska także wspominała, iż w jej domu znajdowało się kilkanaście przedmiotów, które były świadectwem minionych lat walki o polskość. Były to pamiątkowe zegary z Napoleonem i Poniatowskim, portrety, hafty, biżuteria, porcelana, kryształy, należące jeszcze do prababki. „Matka moja pokazała mi kiedyś pozostawiane przez prababkę Rodkiewiczowa duże pudło łańcuszków, rzeźbionych misternie $w$ cienkim czarnym drewnie, a imitującym w miniaturze kajdany więzjenne. Były w tym pudle także czarne broszki, i medaliony z trupimi czaszkami i orzełkami dźwigającymi kajdany. Takimi ozdobami przystrajały Polki swe czarne suknie w czasie żałoby narodowej" 36 .

Maria Grodzicka, opisujac swój rodzinny dom i jego wystrój, podkreślała, iż całe jego życie ogniskowało się wokół salonu, który był przesiaknięty atmosfera historii i przeszłości. Ojcowie, dziadowie, pradziadowie żyli wyłącznie sprawa polską i tęsknotą za niepodległością ojczyzny, za nią walczyli i dla niej pracowali, więc atmosfera codziennego pokoju była tego odbiciem. Nad kanapa wisiały portrety rodzinne, a reszta ścian była jakby wytapetowana licznymi rycinami i sztychami obrazującymi walki o wyzwolenie kraju. Cała martyrologia polska była zawarta $w$ tych licznych obrazkach. „W tym też salonie była szkatułka, ponoć pana Paska, a w niej zamknięte były cenne pamiątki rodzinne, także i tabakiera Tadeusza Kościuszki”" ${ }^{37}$

Helena Duninówna wspominała, iż wszystkie wiadomości, które z rodzeństwem poznali o walkach narodowowyzwoleńczych, wynieśli z domu. Głównie opowiadala o tych wydarzeniach matka. Opowieści swe zazwyczaj obrazowała posiadanymi pamiątkami z czasów powstań narodowych. Miała ona schowane w swoim pokoju, jeszcze po babci: czarny, żelazny krzyżyk na wąskiej aksamitce, malutką cierniową koronę, która przypinało się jako broszkę i medalion z lawy z fotografią swego ojca w powstańczej czamarze. „Miała też relikwię z 1830 roku, srebmą, powleczoną z wierzchu czarną emalią obrączkę z napisem: "Klaudyno, módl się za nami«, jedną z tych, które ku czci i pamięci anioła opiekuńczego powstańców, Klaudyny Potockiej, rozpowszechniano wśród ludności" 38 .

Ważnym czynnikiem kształtowania patriotyzmu w młodym pokoleniu był fakt, iż dzieci brały udział w spotkaniach towarzyskich, wizytach sasiedzkich, rodzinnych, na których często miały okazję przysłuchiwać się rozmowom dorosłych ${ }^{39}$ (wspominało o tym 24 pamiętnikarzy). Na spotkaniach w okolicznych dworach, a takie odbywały się przecież bardzo często, szlachta, ziemiaństwo, a także

\footnotetext{
${ }^{34}$ L. Jabłonowski, Pamiętniki, Kraków 1963, s. 46.

${ }^{35}$ J. z Sikorskich Klemensiewiczowa, Przebojem ku wiedzy. Wspomnienia jednej z pierwszych studentek krakowskich z XIX wieku, Wroclaw 1961, s. 70.

${ }^{36}$ A. Skarbek-Sokołowska, Czas udręki i czas radości. Wspomnienia, Wroclaw 1977, s. 58; podobnie o wykorzystywaniu pamiątek rodzinnych $i$ narodowych $w$ wychowaniu patriotycznym wspominali m.in.: M.K. Dziewanowski, op. cil., s. 40; T.T. Jeż, op. cit., s. 3; Z. Mysłakowski, W poszukiwaniu podstaw pedagogiki. $1890-1971$, red. T.W. Nowacki, Warszawa 1999, s. 8-9; S. Wojciechowski, op. cit, s. 7; W. Wiśniewski, Ostatni z rodu. Rozmowy z Tomaszem Zanem, Warszawa-Paryż 1989, s. 29; G. z Guntherów Puzynina, op. cit, s. 4; A. Piłsudska, Wspomnienia, Warszawa 1989, s. 43.

${ }^{37}$ M. Grodzicka, op. cit., s. 68.

${ }^{38}$ H. Duninówna, op. cit., s. 107.

${ }^{39}$ O edukacyjnym wpływie przysłuchiwania się rozmowom starszych na aktualne tematy polityczne, historyczne, spoleczne pisali m.in.: M. Szypowska, op. cit., s. 46; M. Wolska, B. Oberetyńska, op. cit., s. 110; Pamiętniki lgnacego Baranowskiega..., s. 4; B. Krzywobłocka, op. cit., s. 15!; J. Horoszkiewicz, op. cit., s. 16; F. z Wasilewskich Boberska, Zyciorys, Lwów 1893, s. 3.
} 
oficjaliści pochodzący $\mathrm{z}$ tej samej warstwy społecznej, dzielili się wrażeniami $\mathrm{i}$ wspomnieniami z minionych lat. Nie brakowało wśród nich uczestników wydarzeń politycznych. Uczestnictwo w tego rodzaju rozmowach wpływało, zwłaszcza na chłopców, w sposób istotny, kształtujac ich poglady narodowe. Ale miały one także duży wpływ na dziewczęta. Mocny wpływ na świadomość narodowa wywarło w zaborze rosyjskim powstanie styczniowe. Po jego upadku nie było końca dysputom o walkach, dokonywano analiz zysków, strat, popełnionych błędów. Żołnierze byli stałymi bywalcami wielu dworów, rozmawiano o sprawach narodowych. Atmosfera domów wypełnionych żołnierzami, bohaterami minionych walk, które wspominano, musiała żywo wpływać na świadomość uczestniczacych i obserwujących spotkania dzieci i młodzieży.

Obraz powstańców, będących gośćmi w domach, niekiedy nawet przez dłuższy czas, przywoływało w pamiętnikach wielu autorów. Tadeusz Romanowicz, uczestnik powstania styczniowego wspominał, iż w młodości bywali u jego ojca znani ludzie, uczestnicy walki o niepodległość, m.in. Józef Bem. Tego ostatniego autor widział jedyny raz w życiu, ale gdy przybył on w progi domu, musiał go z czcia całować w rękę̨ ${ }^{40}$. Również Stefania Wilska wspominała, iż jednym z rezydentów ich domu był biorący udział w powstaniu szkolny kolega jej brata, Ignacy Chmieliński. Był on gorącym patriota, i jak sam mawiał, jego celem życiowym było poświęcić wszystko dla odbudowania Polski od morza do morza. „Znosił do naszego domu - pisała Wilska - zakazane dzieła Mickiewicza, Słowackiego i Krasińskiego, różne polityczne broszury i wydawnictwa emigracyjnego świata, jak: »Wiadomości Polskie«, »Przegląd Rzeczy Polskich«, wyjatki z dzieła Lelewela »Polska, dzieje i rzeczy jej«, artykuły Klaczki, pojedyncze numery »Kołokoła «, czyli »Dzwonu« Hercena itp. Wszystko to czytało się częstokroć na głos wspólnie wieczorami i niezaprzeczalnie rozwijało w naszym domu odwagę do jakiegoś udziału w objawiajacym się w narodowym duchu umysłów, pomimo tak srogiego gnębienia przez potwornego Paskiewicza" ${ }^{41}$.

Istotną rolę w kształtowaniu postawy patriotycznej dzieci odgrywały także spotkania $i$ akademie urządzane przez młodzież lub ludzi biorących udział w powstaniu styczniowym. Rodzice często w celach pedagogicznych zabierali dzieci na tego typu imprezy. Stawały się one swoistą szkołą patriotyzmu (15 pamiętników). W trakcie wieczorków deklamowano polskie wiersze, śpiewano pieśni, rozprawiano o dziejach Polski, historii, wygłaszano przemówienia o charakterze narodowym, grano polskie melodie, odbywały się występy chórów lub amatorskich teatrów. Marian Opałek często uczestniczył w tych wieczorkach, zabierany na nie wraz z siostra przez ojca. Końcowym punktem programów artystycznych był zawsze obraz z osób żywych. Centralną figurę obrazu stanowiła najczęściej postać niewiasty odzianej w fałdzistą szatę, okutej w kajdany i wyobrażającej Polskę w niewoli. "Nie pamiętam wszystkiego z tych doniosłych wieczorów, ale niektóre momenty ich szlachetnego patosu pozostały do dziś w mej świadomości (...) Wzruszona, przejęta do głębi publiczność, powstawała ze swych miejsc, odśpiewywała masowo hymn narodowy. Włączałem się watłym głosikiem do tej masówki chóralnej, odczuwając przy tym jakieś ciarki pod skórą i łzy w oczach dziecinnych"42.

Jak wskazuje analiza literatury źródłowej, ogromną rolę w oddziaływaniu na świadomość narodowa młodego pokolenia odegrała literatura polska. Rodzice dużo i często czytywali dzieciom, jeszcze nie umiejącym czytać samodzielnie ${ }^{43}$. W późniejszych latach książka służyła jako pierwszy elementarz, pierwsza czytanka, rodzice wykorzystywali ją do nauki czytania. Jednocześnie była ona niewyczerpanym źródłem historii polskiej, ukazywała piękno i kunszt polskiego języka. Także prasa polska odegrała niemała rolę w przekazywaniu polskich wartości, najnowszych informacji, faktów, publikacji $^{44}$ (dane potwierdzające edukacyjne znaczenie ksiązek i prasy polskiej zawiera 75 pamięt-

40 T. Romanowicz, Listy $i$ wspomnienia, Lwów 1934, s. 2.

4) S. Wiłska, op. cit., s. 7.

${ }^{42}$ M. Opałek, O Lwowie $i$ mojej młodości: kartki z pamiętnika 1881-1901, Wroclaw 1987, s. 118.

${ }^{43} \mathrm{O}$ czytywaniu przez rodziców i rodzeństwo dzieł literatury polskiej mlodszym dzieciom pisali m.in.: K. Kraszewski, Silva Rerum. Wspomnienia i zapiski dzienne z lat 1830-1881. Kronika domowa, Warszawa 2000, s. 32, 224; M.K. Dziewanowski, op. cit., s. 12, 38; E. Polanowski, op. cit., s. 170; S. Milaszewski, op. cit., s. 4; J. Prendowska, Moje wspomnienia, Kraków 1962, s. 21 - 22; Z. Solarzowa, Mój pamiętnik, Warszawa 1976, s. $17,23$.

4 Fakt czytania polskich dzjel literatury narodowej, a także prasy polskiej, pochodzącej z wszystkich trzech zaborów wspominaja m.in.: M. Szypowska, op. cit., s. 25; Swiadek epoki. Listy Elizy z Branickich Krasinskiej z lat 
ników). Ignacy Baliński w swych wspomnieniach dość dokładnie opisywał książki i czasopisma, które towarzyszyły mu od najmłodszych lat. Część z nich czytana była głośno przez rodziców, część przeanalizował sam, gdy już nauczył się czytać. Pierwszymi książkami polskimi, jakie przeczytał samodzielnie były: „Wiązanka Helenki” Klementyny z Tańskich Hoffmanowej, i „Dzień grzecznego Władzia” Jana Chęcińskiego. Czytywał także „Przyjaciela Dzieci”, redagowanego przez Jana Kantego Gregorowicza, ,Wieczory Rodzinne”, które zaczęły wychodzić w 1881 roku. Ojciec chłopca prenumerował „Gazetę Warszawska”, ,Kronikę Rodzinną”, „Bibliotekę Warszawska”, a matka i ciotki „,Bluszcz” Marii Ilnickiej, z modami oraz dodatkami powieściowymi. Z powieści, oprócz czytanej głośno przez rodziców „Szwedzi w Polsce”, zainteresowała chłopca drukowana w odcinkach „Gazety Warszawskiej” (które mój ojciec układał starannie i zszywał do rozpożyczania) „Zemsta Czokołdowa” Józefa Ignacego Kraszewskiego. „Pierwszy wiersz polski poważny - wspominał pamiętnikarz - po wierszykach dziecinnych, odczytał nam mój ojciec. Był to wiersz Antoniego Goreckiego "Śmierć zdrajcy ojczyzny «"45.

Jadwiga z Sikorskich Klemensiewiczowa szczególnie upodobała sobie dzieła Mickiewicza, które w komplecie znajdowały się w bibliq̨tece domowej, a także Słowackiego, Biblię i poezje. Wszystkie te książki pamiętnikarka i jej siostry przeczytały jeszcze pod okiem rodziców, przed rozpoczęciem regulamej nauki z nauczycielem domowym. Służyły one także dziewczynkom jako doskonałe źródło wyboru utworów na wieczorki deklamacji ${ }^{46}$.

Ludwik Krzywicki wspominał, iż z chwila, gdy nauczył się czytać, z zapałem zacząl czytywać różne książki, które znajdowały się w domu rodziców. Najbardziej jednak lubił te podsuwane przez dziadka. Czyływał także prenumerowane przez ojca czasopisma. Największa przyjemność sprawiły mu otrzymane jednego roku w prezencie gwiazdkowym ilustrowane książeczki dla dzieci. ,Niewiele wtedy było ksiażeczek przeznaczonych dla dzieci, ja zaś wcale nie byłem w nie zaopatrzony. Odczytywałem więc "Obrazki« Anczyca, pierwsza książkę, jaką dostałem na własność (...) Siadywałem nad starymi rocznikami pisma »Kmiotek « (...) Dopiero gdy miałem lat osiem, a może dziewięć, zamiast choinki i zwykłych upominków dostałem stos książek, obficie uposażonych w obrazki. Było to moje wielkie ucztowanie z książka. Gdy chodzilem już do szkoły zacząłem też wertować »Kłosy«"47.

Jedna z najbardziej popularnych w ówczesnych latach ksiażek, czytywanych dzieciom przez rodziców, a z chwila nabycia przez dzieci umiejętności czytania - czytanej wielokrotnie przez same dzieci, obok dzieł Mickiewicza, Słowackiego, była „Trylogia” Henryka Sienkiewicza. Wzmianki o tym dziele spotykamy w wielu pamiętnikach ${ }^{48}$. Książki Sienkiewicza, początkowo dość drogie, dostępne

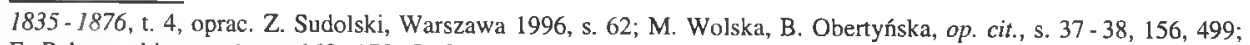
E. Polanowski, op. cit., s. $168-170$; J. Górski, Wspomnienia z minionych lat, Poznań 2000, s. 4; H. Szymanowska-Malewska, Dziennik 1827 - 1857, Warszawa 1999, s. 53; E. Sukertowa-Biedrawina, op. cit., s. 14; J. Porazińska, op. cit., s. 34 -35; P. Górska, op. cit., s. 8-11; J. Kallenbach, op. cit., s. 37; T.T. Jeż, op. cit., s. 40, $73-74$; T.W. Nowacki, Żcie pracowite Heleny Spoczyńskiej, Warszawa 2000, s. 11; Wspomnienia o Ksawerym Świerkowskim [w:] Roczniki Biblioteczne, z. 1, Warszawa-Wroclaw 1980, s. 130; K.M. Górski, J. Wayssenhoff, op. cit., s. 19; J. Galewski, L.B. Grzeniewski, Warszawa zapamiętana. Ostatnie lata XIX stulecia, Warszawa 1961, s. 153 - 157 , 167 - 168; K. Beylin, Dni powszednie Warszawy w latach 1880-1900, Warszawa 1967, s. 242.

45 I. Baliński, op. cit., s. 30-31.

46 "Najulubieńsza naszą lekturą były poezje Mickiewicza, zwłaszcza tom z utworami drobniejszymi $i$ balladami. Trochę później zaczytywałyśmy się w »Grażynie«, »Konradzie Wallenrodzie« i w »Dziadach«, a wkrótce i »Pan Tadeusz zachwycać nas zaczął nadzwyczajnie. "Ś́piewy Historyczne» Niemcewicza i wybór wierszy rozmaitych autorów pod nazwą »Kwiaty rodzinne - oto byly książi, z którymi nie rozstawałyśmy się prawie, czytając i deklamując na pamięć zachwycające nas poezje. Ze Slowackiego »Ojciec zadżumionych« odpowiadał nam wówczas (...) Dodawszy Pismo święte w opracowaniu Klementyny z Tańskich Hoffmanowej, jej »Wiazanie Helenki«, "Pamiąkę po dobrej matce«, wiersze Jachowicza, wówczas bardzo rozpowszechnione i popularne, oczywiście »Robinsona Kruzoe«, »Podróże Guliwera«, „Wspomnienia wygnanki«, »Znakomite niewiasty« Żeleńskiej, i wiele innych, których tytułów i autorów nie zapamiętałam, ma się na obraz lektury, na jakiej się chowałam w owym okresie, przed zaczęciem systematycznej nauki" (J. z Sikorskich Klemensiewiczowa, op. cit., s. 69).

${ }^{47}$ L. Krzywicki, Wspomnienia, Warszawa 1957, s. 80.

48 O czytywaniu „Trylogii" samodzielnie, w gronie rodzinnym podczas wspólnych wieczornych spotkań, a także o odgrywaniu fragmentów dzieła w formie przedstawień pisali m.in.: M. Wolska, B. Obertyńska, op. cit., s. 312 - 313 ; P. Górska, op. cit., s. 8-9; W.J. Grabski, op. cit., s. 47-48; W. Ambroziewicz, op. cit., s. 43-44; J. Galewski, L.B. Grzeniewski, op. cit., s. 157: J. Michalski, op. cit., s. 2. 
były tylko dla rodzin zamożniejszych. $\mathrm{Z}$ czasem jednak stały się one bardzo popularne i docierały do wszystkich niemal środowisk. Edward Ligocki wspominal, iż ojciec jego czytywał mu codziennie fragmenty „Trylogii”: „Ojciec przez długie wieczory czytywał specjalnie dla mnie głośno »Trylogię«, od poczatku do końca. Miałem chyba wtedy lat dziewięć. Czekałem z niecierpliwością, aż nadejdzie pora wieczorna, i słuchałem w skupieniu, dzień w dzień, ojcowskiej lektury" ${ }^{49}$. Pamiętnikarz wspominał też, iż dzieło Sienkiewicza czytano po zagrodach szlacheckich, w domach rzemieślniczych, a znajomość tekstów „Trylogii” stawała się obowiązkiem Polaka. Zbierano się również po chatach chłopskich, a słabo piśmienni prosili, by czytano im ja na głos ${ }^{50}$.

Kazimiera Treterowa także wspominała sprowadzenie „Trylogii” jako jedno z najbardziej pamiętnych wydarzeń dzieciństwa. Kiedy wydano ją drukiem w całości (wcześniej czytano ją w odcinkach prasowych), ojciec sprowadził całość. Dziewczynka z ogromnym namaszczeniem przegląała stronice ksiażki, odszukując ulubione fragmenty. „Najprawdziwsza cudowność »Trylogii« - pisała pamiętnikarka - polegała na piękności opisów przyrody i historycznych, matejkowskich obrazów wydarzeń i bitew, przetransportowanych na słowa. Prawie wszystkie do dziś z siostra pamiętamy" "5l. Także w życiu Marii Grodzickiej „Trylogia” odegrała znacząca rolę. Wspólnie czytywano wieczorami ukazujące się w prasie odcinki powieści. Dzieci mogły więc chodzić później spać, by ich wysłuchać. Bohaterowie dzieła stawali się wzorami osobowymi i postaciami odgrywanymi podczas zabaw. „Wśród wspomnień moich rówieśników poczesne miejsce zajmuja przeżycia związane z ukazaniem się »Trylogii« Sienkiewicza. Dla nas w Psarskiem wrażenia związane z wieczomym czytaniem »Ogniem i mieczem«, a potem »Potopu«, należa do rzędu tych najwyższych i niezatartych" 52 .

Książki polskie, jak wskazuja pamiętnikarze, jeszcze w drugiej połowie XIX wieku nie były powszechnie dostępne dla przeciętnego czytelnika. Dlatego też popularne stało się pożyczanie ich od osób czy rodzin bardziej zamożnych, które stać było na ten niemały wydatek. Również dzieci z sąsiednich dworów pożyczały sobie książki, szczególnie ulubione zaś były te o treści patriotycznej, dzieła literatury narodowej ${ }^{53}$. Dla Henryka Grubera kontakt z rówieśnikami był okazją do poznania wielu polskich ksiązek, których rodzice jego w domu nie posiadali. Wraz z dziećmi z sasiadów wymieniał się on początkowo bajkami, później dziełami najwybitniejszych polskich poetów i pisarzy. Dzięki temu zrodziła się w nim pasja czytania i zamiłowanie do polskich książek: „Przyjaźniłem się z Róża, córką lekarza. Pierwsza w życiu książka z bajkami była pożyczona od niej. Kolejno przychodziły nowe i cała moja początkowa znajomość literatury dla młodzieży, a później pasja czytania miała źródło $w$ książkach pożyczanych od niej. Od niej pochodził też »Zbiór narodowych pieśni polskich«, w której znalazłem pieśni z tytułami: »Boże coś Polskę«, »Z dymem pożarów«, »Jeszcze Polska«" 54 .

Obok książek i prasy polskiej, wspólnych rozmów i wspomnień o wydarzeniach narodowych, organizowaniu deklamacji czy teatrów amatorskich, istotną rolę w kształtowaniu uczuć patriotycznych w młodym pokoleniu odegrało wspólne, rodzinne muzykowanie, śpiew pieśni narodowych, grywanie utworów wybitnych polskich kompozytorów (fakt ten potwierdza 31 pamiętnikarzy). Ignacy Baliński wspominał, iż fragmenty z „Haiki” i pieśni z sześciu śpiewników Stanisława Moniuszki nucono w gronie rodzinnym w różnych wolnych chwilach, a w uroczyste rocznice śpiewano chórem „Boże coś Polskę", „Jeszcze Polska nie zginęła” i „Za Niemen”.55. Niemałą rolę odegrało także odmawianie

${ }^{49}$ E. Ligocki, Dialog z przeszłościa, Warszawa 1970, s. 35.

50 Ibidem, s. 36.

${ }^{51}$ K. Treterowa, op. cit., s. 42.

32 M. Grodzicka, op. cit., s. 45.

53 „Działo się w ten sposób, że gdy tylko książka jaka w okolicy pojawiła się, wnet ja sobie sąsiedzi z rąk do rąk podawali (...)" (T.T. Jeż, op. cit., s. 28); „Dużo wierszy patriotycznych i ksiażek za granica zaboru wydanych krażyło z rạk do rak - skwapliwie chwytane rozgrzewaly ducha Polaków" (J. Prendowska, op. cil., s. 21).

${ }^{54}$ H. Gruber, Wspomnienia $i$ uwagi, Londyn 1976, s. 20.

55 I. Baliński, op. cit., s. 29; o wspólnym, rodzinnym śpiewaniu pieśni patriotycznych i żołnierskich pisali także m.in.: M.K. Dziewanowski, op. cit., s. 39; M. Wolska, B. Obertyńska, op. cit., s. 397; P. Matusik, op. cit., s. 30; 
polskich modlitw i śpiew pieśni religijnych. Wpływały one znacznie na podtrzymanie i zachowanie czystości języka polskiego. Treść ich bowiem przekazywana była już od lat najmłodszych, szczególnie przez matki i babki.

M. Opałek wspominał niemały repertuar pieśni polskich, których uczył go ojciec. Najczęściej śpiewali wspólnie „Pułk czwarty”, a także „Polak nie sługa, nie zna, co to pany”: „Ojciec, trzymając mnie za rękę chodzi po pokoju tam i z powrotem i śpiewa barytonowym głosem o czynie i tragedii czwartaków, tak jak to pisał Jan Nepomucen Kamiński. Drepczę drobnymi kroczkami przy ojcu, chwytam watki melodii, fragmenty tekstu" ${ }^{56}$. Także matka często śpiewała, obok kołysanek dla dzieci, także pieśni patriotyczne, np. „Lecą liście z drzewa”. Oboje rodzice Opałka bardzo lubili grać także na fortepianie, dlatego duża uwagę przywiazywali do nauki dzieci gry na tym instrumencie. Repertuar melodii na fortepian był starannie dobrany, a zadaniem jego było rozbudzenie miłości dla muzyki polskiej. Korzystano bowiem ze zbioru nut pt. „Wieniec melodii polskich”, w których zamieszczono min. takie utwory jak: "Gwiazdkę" Kazimierza Lubomirskiego, „Za Niemen precz” Augusta Bielowskiego, a także „Boże coś Polskę”, „Polonez Kościuszki”, „Dalej bracia do bułata”, „Cześć polskiej ziemi, cześć”, „W krwawynf polu srebme ptaszę", ,Tam na błoniu błyszczy kwiecie”, „Ostatni mazur" czy "Gdybym ja byla słoneczkiem na niebie" Chopina ${ }^{57}$.

Warto podkreślić, iż stosowane przez rodziców sposoby wychowania patriotycznego w istotny sposób wspomagane były wychowaniem religijnym (dane na ten temat odnajdujemy w 27 pamiętnikach). Patriotyzm i religijność bowiem w badanym okresie przenikały się wzajemnie. Aby być patriotą $w$ tamtych czasach, należało być także człowiekiem zaangażowanym religijnie. Kto kochał ojczyznę, musiał również kochać Boga. Grasylda Malinowska w swych wspomnieniach podkreślała, iż dziadek jej zawsze laczył nauczanie religii $\mathrm{z}$ nauka historii i wpajaniem patriotyzmu. „Uczył nas poznawać Boga $\mathrm{i}$ historię tej biednej ojczyzny - pisała o dziadku - bo był naocznym świadkiem ostatniego rozbioru Polski i wszystkich jej klęsk. On wpajał milość do języka, do tych czynów, których nas wiara uczy, powtarzajac, że wiara bez uczynków jest martwa. Mówił o zdrajcach i wrogach, uczył katechizmu. Co wieczór śpiewał z nami litanię do Matki Boskiej, przygrywając na skrzypcach"s8.

Szczególnie zespolenie uczuć religijnych z emocjami o charakterze patriotycznym było widoczne w okresach poprzedzających czyny zbrojne i w czasie ich trwania. Na poczatku lat sześćdziesiatych XIX wieku społeczeństwo polskie manifestowało patriotyzm, uczestnicząc w mszach i nabożeństwach za ojczyznę ${ }^{59}$. W XIX wieku nastapiło zjawisko zespolenia się polskości z katolicyzmem. Mogło się to dokonać tylko w społeczności ludzi wierzących, przywiązanych do religii wyznawanej prze siebie i traktowanej jak naturalne dziedzictwo ojców. To stopienie się narodowości i wyznania miało wiele wymiarów. Przykładem może być kult św. Stanisława, pierwszego patrona Polski, czy Matki Bożej jako Królowej Polski.

M. Opałek pisał, iż w okresie jego dzieciństwa $i$ lat młodzieńczych niemałą rolę $w$ budzeniu i podtrzymywaniu ducha narodowego odgrywały manifestacje religijno-patriotyczne w kościołach.

B. Krzywobłocka, op. cit., s. 148; J. Horoszkiewicz, op. cit., s. 17 - 18; K. Błeszyński, O mnie i nie o mnie, Łódź 1963 , s. 50, J. Targalski, op. cit., s. 30; A. Dorabialska, Jeszcze jedno zycie, Warszawa 1972, s. 11; W. Sieroszewski, Pamiętniki i wspomnienia, Kraków 1959, s. 15; Moi rodzice, oprac. M. Skwarnicki, Warszawa 1965, s. 35; M. Leśkiewicz, Kartki ze starego albumu, Kraków 1975, s. 23-27; W. Miłaszewska, Wspominamy, Poznań-Lublin 1939 , s. 32; Z. Solarzowa, op. cit., s. 17.

${ }^{56}$ M. Opalek, op. cit., s. 106.

57 Ibidem.

${ }^{58}$ G. Malinowska, Pamiętnik kresowej nauczycielki z lat 1833-1921, Bydgoszcz 1995, s. 11; podobnie o nauczaniu religii $w$ połaczeniu $z$ milością Ojczyzny pisali m.in.: M. Wolska, B. Obertyńska, op. cit., s. 369; Z. Filipowicz, Sunalskie lata Marii Konopnickiej, Warszawa 1976, s. 20-21; B. Suchodolski, op. cit., s. 9; J. Bocheński, Wspomnienia, Kraków 1993, s. 15; J. Slomezyńska, Maria Konopnicka. Życie i twórczość, Łódź 1946, s. 12; F. Bagieński, Wspomnienia starego Wotyniaka, Warszawa 1987, s. 33; W. Sieroszewski, op. cit., s. 11; W. Wiśniewski, Pani na Brezenikach. Rozmowy z Helena z Zanów Stankiewiczowa. Londyn 1991, s. $78-79$.

59 Bracia Pławińscy uczestniczyli w organizowanych nielegalnje przez rodziców domowych tajnych nabożeństwach za Ojczyznę, a w czasie wielkiego postu, ,na intencje szybkiego wyzwolenia Polski z niewoli cala rodzina ściśle go przestrzegała" (J. Targalski, op. cit., s. 29). 
Uroczyste nabożeństwa w rocznicę Konstytucji 3 Maja i walk o niepodległość gromadziły w kościołach tłumy uczestników, głównie młodzież akademicką i uczniów szkół średnich, ale także polskie rodziny, często z małymi dziećmi. Śpiewano po nabożeństwach pieśni „Boże, coś Polskę”, „Boże Ojcze, Twoje dzieci" i „Z dymem pożarów" 60. Grasylda Malinowska także brała udział w takich manifestacjach: „I u nas zaczęły się manifestacje po kościołach. Zaczęliśmy śpiewać „Boże, coś Polskę«, wdziewać żałobę. Kublicki proboszcz przezacny ks. Steckiewicz nie przeszkadzał, ojciec zachęcał (...)"61. Także Teodora z Kosmowskich Krajewska już jako kilkuletnie dziecko uczestniczyła wraz ze swa nianią w nabożeństwach patriotycznych. Niewiele jeszcze rozumiejac, śpiewała wraz z tłumem Polaków „Boże, coś Polskę": „Ksiądz zaintonował pieśń, a cały ten zbity tłum ludzi zawtórował ten hymn zgnębionej niewola duszy narodu a takim żalem, i taka moca, że całe powietrze aż do stropu zafalowało, a płomienie świec zadrżały. Wchłaniałam cały smutek tych łez i brałam na drogę życia ten okrzyk rozpaczy"62.

Konieczne jest tutaj jednak podkreślenie, iż uproszczeniem byłaby teza, że aby być patriota, konieczne było zaangażowanie religijne. Funkcjonowali przecież działacze niepodległościowi o postawach wolnomyślicielskich. Podobnie, nie należy uogólniać, iż wszyscy Polacy zaangażowani religijnie udzielali się $w$ walce o niepodległy byt narodowy ${ }^{63}$. Kazimiera Treterowa wspominała, iż w domu ich religia katolicka była zepchnięta na margines życia. Rodzice twierdzili, iż jest tak dużo rozmaitych spraw i wydarzeń w życiu człowieka, które chłoną́ miały dzieci, iż religia nie może odegrać zbyt istotnej roli. Ojciec jej nigdy do kościoła nie chodził, zaś dzieciom tłumaczył, że Jezus był pierwszym socjalista. „My, młodsze siostry, nie byłyśmy wychowane w sztywnych kanonach katolickich. W szkole chodziło się z klasa co niedzielę do kościoła, ale w domu nie zachowywało się żadnych postów, z wyjątkiem Wilii i Wielkiego Piątku" "‘4.

Analizując wychowanie patriotyczne w rodzinie polskiej Królestwa Polskiego w drugiej połowie wieku XIX i w poczatkach wieku XX należy zaznaczyć, iż do tego patriotycznego, i jak się wydaje, szeroko we wszystkich klasach rozpowszechnionego modelu wychowania, nie wszyscy oczywiście dochodzili (potwierdza to 18 pamiętnikarzy). W wielu rodzinach bowiem panowal egoizm i konformizm, lęk przed przeciwstawieniem się zaborcy, w innych dobre wychowanie polegało na zakłamanym utrzymywaniu pozorów i robieniu tego, co wypada na zewnątrz, publicznie, przy jednoczesnej małostkowości w życiu prywatnym. Szczególnie arystokracja i szlachta posiadająca w miarę upływu czasu i oddalania się możliwości powrotu do stosunków przedrozbiorowych, stawały się coraz mniej aktywne w ruchu narodowym, by wreszcie wejść na drogę lojalizmu wobec cara Rosji, wiernego służenia krajowi zaborczemu, w nadziei oczywiście na ulgi, łaski i dobrodziejstwa ze strony tej władzy $^{65}$. Wiele więc osób wolało zachowywać się tak, jak nakazywała władza carska, by nie osłabić swej pozycji, nie stracić majątku, nie pójść do więzienia, czy nie zostać zesłanym ${ }^{66}$. Zamiast konspiracyjnej pracy na rzecz kraju oddawano się aktywnemu życiu towarzyskiemu i rozrywce. Często nawet zdarzało się, że sprzedawano majątki, by wieść lżejsze $\mathrm{i}$ weselsze życie w mieście, a niejeden

${ }^{60}$ M. Opałek, op. cit., s. 122

${ }^{61}$ G. Malinowska, op. cit., s. 29.

62 T. z Kosmowskich Krajewska, op. cit., s. 30.

${ }^{63}$ A. Ładyżyński, op. cit., s. 21.

${ }^{64}$ K. Treterowa, op. cit., s. 43; również i inni pamiętnikarze pisali o zepchnięciu religijności na margines życia rodzinnego: ,(...) rodzice moi nie naprzykrzali się zbytnio koścjołowi. Nie znaczy to jednak, że byli ateistami (...) Patrzac na naturę i jej cuda, jej madrość, znacznie wyższą od mądrości mędrców świata, w całej naturze widzieli Boga i ja go wtedy w niej widzialem" (J. Skotnicki, Przy sztalugach i przy biurku. Wspomnienia, Warszawa 1975, s. 13); Z. Solarzowa, op. cit., s. 61

${ }^{6.5}$ A. Zarnowski, Ojczyzna byl jezyk i mowa. Kultura polska a odbudowa niepodlegtości w 1918 roku, Warszawa 1978 , s. 45 .

${ }^{66} \mathrm{O}$ braku wychowania patriotycznego, z powodu obaw ojca przed prześladowaniami zaborcy, tak pisał jeden z pamiętnikarzy: „W domu ojca mego nigdy nie słyszałem rozmów czy deklamacji patriotycznych. Tradycja rodzinna nie przekazywała żadnych uderzających faktów z przeszłości (...) Ojciec wiódl żywot cichy, rodzinny, ale do egzáttacji patriotycznych chyba nie byl skłonny. Sądzę, że był przy tym bojaźliwy" (Pamiętniki lgnacego Baranowskiego..., s. 6). 
młody człowiek opuszczał kraj i robił karierę za granicą. Dzieci wychowywane w takich rodzinach bądź zupełnie biernie godziły się z zastana sytuacja kraju ojczystego i nie robiły nic, by ją zmienić, bądź dorastajac, rozumiały trudną sytuację Polski i wbrew woli rodziców stawały się czynnymi działaczami patriotycznymi.

Jako że duża część omawianego czasu stanowił okres pozytywizmu, będący reakcją na nieudane powstanie z 1863 roku, zwłaszcza starsza część społeczeństwa zaczęła szerzyć postawę pogodzenia się ze swym losem, z niewolą rosyjska, wyrzeczenia się marzeń o niepodiegłości. W zamian dążono do ugruntowania siły i odporu społeczeństwa polskiego opierajac się na dobrobycie ekonomicznym i podtrzymaniu prawdziwie polskiej kultury ${ }^{67}$. Indywidualne bogacenie się miało być zarazem cnota obywatelska, gdyż bogaciło kraj, stawało się podstawą do zachowania polskiej odrębności wobec wrogiego zaborcy. W rzeczywistości jednak te podniosłe hasła bogacenia się w celu polepszenia sytuacji całego narodu, nie znalazły żadnego odbicia w rzeczywistości. Młodzi ludzie, wychowywani w takich wartościach, jak maksymalne gromadzenie dóbr materialnych, pieniędzy i majątku, nie myśleli o potrzebie wyswobodzenia ojczyzny spod jarzma zaborcy. Jadwiga z Sikorskich Klemensiewiczowa tak opisywała ówczesne zapędy młodych ludzi do zdobywania posad, robienia kariery i zbijanja fortuny: „Młode pokolenie, wyrastajace w atmosferze pozytywizmu - naturalnie tyczy się to tylko chłopców, gdyż kobiety nie liczyły się jeszcze jako czynnik społeczny - wcześnie już układało sobie plany co do przyszłych swych intratnych posad na stanowiskach inżynierów, architektów, lekarzy, adwokatów, dyrektorów fabryk różnego rodzaju. Dla odpowiedniego kształcenia się wyjeżdżano za granicę, do Niemiec, Francji, bo dyplom zagraniczny powiększal szansę szybkiego osiagnięcia materialnego powodzenia" ${ }^{68}$.

Podobnie lata swej młodości wspominała Stefania Wilska. Sama wychowana przez rodziców w duchu patriotyzmu, poszanowania przeszłości i tradycji narodowych, w kulcie bohaterów i walk narodowowyzwoleńczych, nie mogła zrozumieć części otaczającej jej młodzieży lat sześćdziesiątych wieku XIX. Rówieśnicy jej bowiem, spędzając czas na rozrywkach, spotkaniach towarzyskich, wyjazdach na wieś, za granicę, zachowywali się tak, jak gdyby nie istniały sprawy narodowe, a najistotniejsze było ich własne, rozrywkowe i dostatnie życie. Dlatego też życie towarzyskie i spotkania z przyjaciółmi stanowiły jeden, zewnętrzny świat pamiętnikarki, zaś jej dom rodzinny był drugim, odrębnym światem: „Żyłam przeto między dwoma bardzo różnymi światami, czerpiąc z jednego przyjemną i właściwą młodemu wiekowi zabawę, a z drugiego zaś głębokie, przenikające całą istotę, poczucie szerszych obowiazków, dążenie do ideału, wskazanego nam przez ofiarników narodowych męczeństwem i śmiercia, dających świadectwo niezniszczalności duchowych sił narodu"69.

Jak wskazuja źródła pamiętnikarskie, były także rodziny polskie, w których nie odbywało się wychowanie patriotyczne ${ }^{70}$. O takim właśnie braku patriotycznego wychowania w domu rodzinnym pisała Maria Bohuszewiczówna. Patriotyzm wyniosła głównie z pensji żeńskiej. Rodzice jej zaś unikali wszelkich ,niebezpiecznych” rozmów. Przystosowali swój tryb życia do otoczenia w obawie przed

${ }^{67}$ „W naszym domu mało mówiło się na tematy patriotycznego zaangażowania, obowiązywał jakby duch wygodnego oportunizmu pod pretekstem "pracy organicznej«. Panował więc nastrój milczacego przyzwolenia na nieporuszanie draźliwych tematów niewoli narodowej" (S. Włoszczewski, op. cit., s. 16).

${ }^{68}$ J. z Sikorskich Klemensiewiczowa, op. cit., s. 10.

69 "Wspomnienia życia towarzyskiego uderzaja mnie tym, że w wielu znajomych nam domach nie spotkałam jeszcze ani śladu zainteresowania się mlodzieży sprawami publicznymi. Mówiło się o planach kamawalowych, o teatrze, o muzyce, wystawie Towarzystwa Sztuk Pięknych, nowych powieściach, wrażeniach przywiezionych z wycieczek letnich na wieś lub za granicę, o ślubach, zaręczynach, o słynnych pięknościach, spomiędzy których zawsze jakaś gwiazda królowała na horyzoncie balów warszawskich i wśród takiego nastroju, tak zresztą naturalnego i właściwego zebraniom towarzyskim, zauważyłam, że większości spotykanej młodzieży płci obojga nie przychodziło nawet na myśl zająć się czymś ważniejszym; że na przykład sprawy Towarzystwa Rolniczego, wojen włoskich, działań rewolucyjnych w całej Europie, że nazwiska Klaczki, Mierosławskiego, Garibaldiego, Mazziniego, Hercena, że Napoleon III, Magenta, Solferino, i tym podobne nazwy, czy nazwiska nic ich nie obchodzily i że mało co o nich wiedzieli. Trzeba było do takiego nastroju umieć się dostosować" (S. Wilska, op. cit., s. 27).

71' Pisali o fakcie tym m.in.: J. Siemiński, Ewunia. Szkic na podstawie dzienników, albumów i innych papierów pośmiertnych, Lwów 1888, s. V; w domu Delfiny Potockej „,wychowanie dzieci było najskrupulatniej francuskie (...), inną cechę stylu życia stanowił kosmopolityzm, a z drugiej ugodowość wobec zaborców" (E. Rudzki, op. cit., s. 10). 
żandarmami i pograżyli się w życiu towarzyskim. Dom pełen był kuzynek, kuzynów, ciotek, wujów, nie pracujacych, rozmiłowanych w plotkach. Młodzi panowie myśleli tylko o karierze, pieniadzach i bogatej żonie, dziewczęta wyłącznie o swym wyglądzie i powodzeniu u mężczyzn, o tym, by jak najprędzej wyjść za mąż. Ludzie ci żyli głównie z kapitałów, ze sprzedawanych majątków ziemskich, z kamienic czynszowych, z najrozmaitszych kombinacji finansowych. Nikt z nich nawet nie myślał o tym, co zrobić, by pomóc uciemiężonej ojczyźnie ${ }^{71}$.

Jak również wynika $z$ analizy źródel, w części polskich rodzin żyjących w zaborze rosyjskim, panował dualizm zachowań, polegający na tym, iż w domach swych zachowywali oni wszelkie tradycje i zwyczaje polskie, szanowali ojczysty język i historį̧, starali się kształtować w dzieciach postawy patriotyczne, zaś na zewnątrz, w życiu publicznym, służyli wiernie zaborcy. Feliks Kon w swych wspomnieniach obszernie opisywał tę sytuację, a słowa jego doskonale oddawały to, co działo się w tych właśnie rodzinach, dlatego warto przytoczyć je w całości: „Ogniem i mieczem, szubienicami i katorga ujarzmiła Rosja carska zbuntowana Polskę. Krwawy reżim panował nie tylko w Warszawie, ale i w całej Polsce. Zwycięzcy despoci, którzy przyjeżdżali do Polski, nie widzieli łez, jak mówi Słowacki, widzieli tylko domy ukwiecone kobiercami. Ale to, co działo się wewnątrz tych domów, ukryte było przed oczami wrogów... Tam właśnie wzrastała i krzepła nowa, młoda Polska. Tam wzrastały dzieci, które zanim jeszcze nauczyły się pacierza, umiały już na pamięć hymny patriotyczne. Wzrastała młodzież, dla której przywieziony potajemnie z Galicji portret Kościuszki był większa świętością niż święte obrazy, niż krucyfiks. Ujawniał się przedziwny kontrast... W domu rodzinnym kultywowano tradycje, święte tradycje walki, a poza domem toczyło się życie sprzeczne z tymi tradycjami. Polak - patriota w swoim ognisku domowym - służył wiernie duszą i ciałem jako urzędnik rosyjskiemu samodzierżcy, który usiłowal wszelkimi sposobami przeobrazić Polskę w »Priwiśliańskij kraj«; Polak - patriota, kupiec na warszawskim rynku, wypierał w walce konkurencyjnej towary łódzkie... towarami moskiewskimi, itd., itd. Ta sprzeczność między kultem, a życiem, między słowem, a czynem musiała rzucać się w oczy dorastającemu pokoleniu, musiała narzucać mu zagadnienia nie znane wcześniejszym pokoleniom. Jest rzeczą zrozumiałą, że przy takich metodach wychowawczych ów duch buntu, który musiał nurtować młodzjeż ujarzmionego kraju, potężniał jeszcze bardziej i coraz silniej pchał ją na drogę rewolucji. A ponieważ całe zło przypisywało się zaborcom Polski, więc owa drogą była droga walki o niepodległość"72.

Analizując zagadnienie wychowania patriotycznego $w$ rodzinie polskiej zaboru rosyjskiego w drugiej połowie XIX i początkach wieku XX, nie sposób pominąć skutków i rezultatów, jakie wywarło ono na młodych Polakach zarówno w dzieciństwie, jak i w całym ich przyszłym, dorosłym życiu (potwierdza to 43 pamiętnikarzy). Należy tu także podkreślić siłę, z jaka oddziaływały na ich umysły wszelkie w tym kierunku prowadzone działania rodziny. Nie tylko bowiem zaczytywali się oni podsuwanymi przez rodziców polskimi ksiażkami, z zapałem brali udział w nabożeństwach patriotycznych, uczyli się historii Polski, ale nawet samodzielnie próbowali pisać wiersze, wyrażające miłość do kraju ojczystego, piosenki, układali specjalne litanie w sprawie wolności Polski ${ }^{73}$. Przy tym doskonale rozumieli sens i znaczenie wydarzeń politycznych, których niejednokrotnie byli bezpośrednimi świadkami. Wielokrotnie wspominana już Jadwiga z Sikorskich Klemensiewiczowa tak opisywała jedno z takich istotnych zajść na scenie politycznej końca XIX wieku: „Chcę mówić o zamachu bombowym na cara Aleksandra II dokonanym skutecznie przez rewolucyjną rosyjska partię "Narodnaja Wola « w roku 1881 i o wielkim zrywie gorącej miłości Ojczyzny, jaki odczułam głęboko w mej duszy pod wpływem tego zdarzenia. Miałam już wtedy 10 lat (...) i dobrze rozumiałam znaczenie tych obchodów patriotycznych, jakie się u nas i znajomych tajnie odbywały w dni ważniejszych rocznic

\footnotetext{
${ }^{71}$ I. Kopytowska, Szalona dziewczyna - opowieśc o Marii Bohuszewiczównie, Warszawa 1965, s. 8-9.

72 F. Kon, Narodziny wieku. Wspomnienia, Warszawa 1969, s. 14-15.

73 Jeden 2 pamiętnikarzy tak pisał o sile oddzialywań patriotycznych rodziny na mlode pokolenie: „Zaczęły się opowiadania o dziejach Polski, umiejętnie, barwnie podane, śpiewanie zakazanych pieśni. Boże, cóż to byly za przeżycia, jakaż się miłość dla umęczonej Ojczyzny budzila, jakie pragnienie ofiar dla Niej. »O Matko nasza, o Ojczyzno święta, my Twoje dzieci, my skruszym twe pęta« - przysięgaliśmy sobie w duszy" (Moi rodzice..., s. 35).
} 
narodowych. Zdawało mi się, że kocham Polskę po swojemu, czułam się Polką i niewola, w jakiej naród nasz pozostawal, nie była dla mnie tylko pustym słowem, lecz odczuwałam jej istotny ciężar w przeżywanych lub zasłyszanych jej przejawach" 74 .

Podobnie o rezultatach stosowania tak licznych środków wychowania patriotycznego w rodzinie pisała Romana Pachucka: „Opancerzono nas, dzieci, nienawiścia do wroga, budowano między nim a młodym pokoleniem mur nie do przebicia, a kto go przekroczył, ustępował z polskich rodzin. Była to swoista forma naszego patriotyzmu, a jego przejawy to tajne obchody rocznic narodowych, czytanie książek zakazanych, składanie wieńców na grobie "pięciu poległych«, śpiewanie pieśni patriotycznych"75.

Jak wynika z powyższych analiz literatury pamiętnikarskiej, patriotyczny sposób wychowywania przez rodziców miał ogromne znaczenie dla utrzymania w młodym pokoleniu tożsamości narodowej, a także dla całego jego przyszłego życia. To bowiem, jak rodzice wychowywali dziecko, przenosito się na wzory oddziaływań wychowawczych młodego pokolenia ${ }^{76}$. Tak, jak przekazywali im oni swa wiedzę, umiejętności, postawy, jak zapoznawali ich z ojczystą historia, literaturą, sztuka, tak młodzi ludzie z pewnością w podobny ^sposób przekazywali te same wartości swym dzieciom. Doskonale patriotyczny wpływ rodziny i tradycji narodowej na swe życie opisała we wspomnieniach z młodości Stefania Wilska: „Stwierdzam po raz tysięczny wielka prawdę, iż wpływy domowe, rodzicielskie, rodzinne, jeżeli ugruntowane są na rozumnej miłości, niewzruszonej zasadzie obowiązku i tradycji narodowej, czci gniazda rodzinnego, daja człowiekowi na całe życie skarb, którego posiadanie wysłowić się nie da, ale który jest taki, jak to powiedział Jan Kochanowski o cnocie:

"Cnota skarb wieczny, cnota klejnot drogi,

Tegoć nie wydrze nieprzyjaciel srogi,

Nie spali ogień, nie zabierze woda,

Nad wszystkim innym panuje przygoda«".

„Otóż był ogień pożaru - pisała dalej pamiętnikarka - była woda, nieprzyjaciel srogi znęcał się nad naszym narodem nieustannie. Nad dostatkami tego świata zapanowala twarda przygoda, ale ponad to wszystko wynieśliśmy $\mathrm{z}$ rodzicielskiego domu to, co nas krzepiło w późniejszych walkach życiowych"77.

Wyraźnym rezultatem domowego patriotycznego wychowania była także pamięć i szacunek dla bohaterów narodowych. Dzieci szczyciły się tym, że ich przodkowie ruszali z bronią w ręku walczyé o niepodległą ojczyznę. Sami więc także pragnęii przyczynić się do odbudowy niepodległości kraju. Udział więc wielu Polaków w walkach narodowowyzwoleńczych był zasługa oddziaływania rodziny i najbliższego otoczenia na postawy patriotyczne walczacych o poprawę losów kraju. Feliks Kon - jak już o tym wspomniano - pisał, że „przy takich metodach pedagogicznych ów duch buntu, który musiał nurtować młodzież ujarzmionego kraju, potężniał jeszcze bardziej i coraz siniej pchał ją na drogę rewolucji. A ponieważ całe zło przypisywało się zaborcom Polski, więc owa droga była drogą walki o niepodległość Polski" ${ }^{78}$.

Różnorodność środków i wielość oddziaływań patriotycznych w domu rodzinnym przyczyniała się także do wpajania pędu do wiedzy, nauki, poszerzania swych horyzontów, by swą pracą naukową, czy działalnością społeczną wydźwignąć ojczyznę z upadku. W wielu więc pamiętnikach znajdujemy atmosferę walki kobiet o dopuszczenie do studiów wyższych, na uniwersytety, a także gwałtowny

${ }^{74}$ J. z Sikorskich Klemensiewiczowa, op. cil., s. 68.

${ }^{75}$ R. Pachucka, op. cit., s. 13.

${ }^{76} \mathrm{O}$ pozytywnych rezultatach wychowania patriotycznego $w$ domu rodzinnym pisali m.jn.: K. Kraszewski, op. cit., s. 502; M. Szypowska, op. cit., s. 28; K. Pruszyński, op. cit., s. 56; Stanisława Michalskiego autobiografia.., op. cit., s. 195-196; W. Żółkiewska, op. cit,, s. 165; J.D. Muśnicki, Moje wspomnienia, Warszawa 1935, s. 35; S. Wojciechowski, op. cit., s. 7; S. Miłaszewski, op. cit., s. 26; J. Rosen, Wspomnienia 1860-1925, Warszawa 1933, s. 37; W. Sieroszewski, op. cit., s. 27; W. Lasocki, Wspomnienia z mojego zycia, t. 1 - W kraju, Kraków 1933, s. 95; Moi rodzice..., s. 32,35 .

${ }_{77}$ S. Wilska, op. cit., s. 27.

${ }^{78}$ F. Kon, op. cit., s. 14. 
rozwój ruchu feministycznego. Wiele działaczek społecznych, politycznych, walczących o prawa robotników, nauczycielek, kobiet, które przyczyniły się do rozwoju wielkiej sprawy oświaty ludowej, swe heroiczne postawy zawdzięcza przykładowi i wychowaniu rodziców. Janina Kasprzakowa podkreślała wpływ patriotycznej atmosfery domowej na podjęcie przez nia w dorosłym już życiu działalności oświatowej: „Rozmowy dziewczynki, obdarzonej darem obserwacji zjawisk spolecznych i politycznych, z różnymi znajomymi rodziny, szczególnie sprzyjały przeradzaniu wszczepionej przez rodziców miłości ojczyzny w trwałe zainteresowanie jej dziejami społeczno-politycznymi, w gotowość niesienia zdobytej wiedzy początkowo do rodzin i chałup chłopskich, a potem do robotników Łodzi, Warszawy, Zagłębia"79.

Podsumowując dokonane tu ustalenia należy stwierdzić, iż rodziny polskie odegrały znacząca rolę w procesie kształtowania patriotyzmu w młodym pokoleniu. To właśnie od tych patriotycznych postaw, prezentowanych przez członków rodziny, od wpajanego przez nich systemu wartości zależało późniejsze powodzenie wszelkich dążeń, zmierzających do przeobrażenia życia społecznego oraz do odzyskania, a następnie utrwalenia niepodległego bytu państwowego.

Jak wynika $z$ analizy źródeł pamiętnikarskich, w wychowaniu patriotycznym dzieci i młodzieży udział brali wszyscy niemal członkowie rodzin polskich, a działania ich nie zawsze były celowe i zaplanowane. Wykorzystywali oni różnorodne środki oddziaływania, takie jak: wspólne rozmowy, wspomnienia $\mathrm{z}$ walk i powstań, opowieści dotyczące historii kraju, wycieczki do miejsc kultu narodowego i walk narodowowyzwoleńczych, prasa i książki polskie, muzykowanie (granie utworów polskich kompozytorów i śpiewanie polskich pieśni patriotycznych), wieczorki deklamacji, teatry amatorskie, żywe obrazy.

Ważnym czynnikiem wpajania dzieciom miłości do ojczyzny było podkreślanie na każdym niemal kroku przez rodziców czy innych członków rodziny niechęci do zaborcy, kultywowanie zwyczajów żałoby narodowej: zaprzestanie zabaw, tańców, noszenie narodowych lub czarnych strojów. Wymagano także od najmłodszych szacunku do miejsc pamięci narodowej i grobów powstańczych, prezentowano im pamiątki rodowe i narodowe, kolekcje obrazów i sztychów. Słowem niemal wszyscy członkowie rodzin patriotycznych starali się stworzyć w domu taką atmosferę kultu i miłości dla Polski, aby dziecko przesiakło nią do tego stopnia, by nie ulec niszczacemu wpływowi rusyfikacji.

Swoistym uzupełnieniem wychowania patriotycznego było wychowanie religijne. Na kartach wielu wspomnień odnaleźć można bowiem wzmianki o łączeniu miłości Boga z miłością Ojczyzny. $\mathrm{W}$ ramach tak realizowanego wychowania religijnego, obok nauki pacierza $\mathrm{w}$ języku polskim, pieśni, modlitw, czytania katechizmu i Biblii, często zabierano dzieci na nabożeństwa patriotyczne, obchody ważnych rocznic narodowych organizowane w kościołach, msze w intencji odzyskania niepodległości.

Istotnym wydaje się także zaznaczenie, iż analizujac zagadnienie wychowania patriotycznego w rodzinie, nie można pewnych zjawisk i zdarzeń uogólniać. Jak już bowiem wcześniej wspomniano, a co wyraźnie podkreślali autorzy pamiętników, nie wszystkie rodziny były patriotyczne i nie wszystkie wpajały uczucia narodowe. Jak podaja analizowane źródła, były bowiem i takie, które przedkładały dobrobyt materialny nad walkę o wyzwolenie kraju, podporządkowywały się zaborcy, zyskując spokój i nietykalność.

Podobnie, nie wszyscy członkowie rodzin prezentowali prawidłowe postawy wychowawcze, nie posiadali odpowiedniej wiedzy pedagogicznej, nie wszyscy stosowali starannie dobrane środki i metody wychowawcze, które wpłynęłyby na ukształtowanie postawy patriotycznej w młodych Polakach. Jednak fakt, że naród polski przetrwał niewolę, świadczy o tym, że rodziny będące przekaźnikami kultury polskiej stanowiły istotną część społeczeństwa, a także, że były mocnym fundamentem stabilizującym społeczeństwo. To w tych właśnie rodzinach przekazywano wartości i postawy, i urabiano je w taki sposób, że wykazywały trwałość na całe życie. Odpowiedni zaś dobór środków i metod wychowawczych sprawiał, co wyraźnie wynika z analizowanych wspomnień, że wychowanie takie rzeczywiście odnosiło pożądane rezultaty i skutki.

\footnotetext{
79 J. Kasprzakowa, Maria Koszutska, Warszawa 1988, s. 14.
} 
Mimo więc tych wszystkich przykładów, mówiących o braku patriotyzmu wśród Polaków Królestwa Polskiego, nie ulega jednak wątpliwości, iż część ludności polskiej, w mniej lub bardziej aktywny sposób, dbała o utrzymanie tożsamości narodowej młodego pokolenia. Swoistą zaś ostoja polskości, źródłem tradycji i obyczajów narodowych, była rodzina polska i panująca w niej patriotyczna atmosfera domowa. Na podstawie wykorzystanych źródeł pamiętnikarskich można stwierdzić, iż rodziny polskie, z wyłączeniem oczywiście tych, w których panował lęk przed zaborcami i bierne podporządkowanie się caratowi, starały się przekazać młodemu pokoleniu najistotniejsze wartości i tradycje narodowe, poszanowanie języka i historii polskiej, wpoić skłonność do poświęceń dla ojczyzny. 